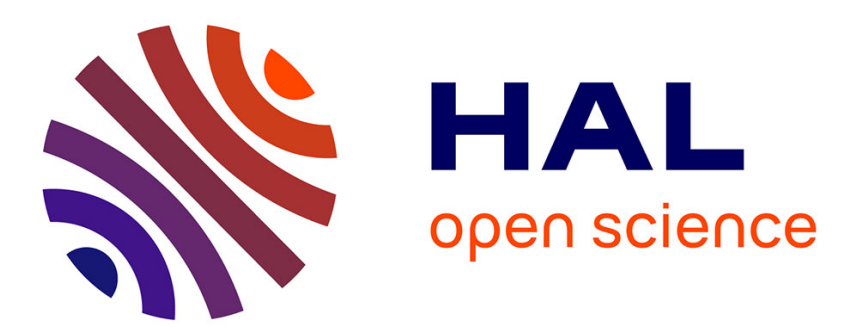

\title{
Investigating physical and thermal interactions between lava and trees: the case of Kilauea's July 1974 flow
}

\author{
Magdalena Oryaëlle Chevrel, Andrew Harris, Alexian Ajas, Jonas Biren,
} Lucia Gurioli, Laura Calabrò

\section{- To cite this version:}

Magdalena Oryaëlle Chevrel, Andrew Harris, Alexian Ajas, Jonas Biren, Lucia Gurioli, et al.. Investigating physical and thermal interactions between lava and trees: the case of Kilauea's July 1974 flow. Bulletin of Volcanology, 2019, 81 (6), 10.1007/s00445-018-1263-8 . hal-02538123

HAL Id: hal-02538123

https://hal.uca.fr/hal-02538123

Submitted on 26 Nov 2020

HAL is a multi-disciplinary open access archive for the deposit and dissemination of scientific research documents, whether they are published or not. The documents may come from teaching and research institutions in France or abroad, or from public or private research centers.
L'archive ouverte pluridisciplinaire HAL, est destinée au dépôt et à la diffusion de documents scientifiques de niveau recherche, publiés ou non, émanant des établissements d'enseignement et de recherche français ou étrangers, des laboratoires publics ou privés. 
1 Investigating physical and thermal interactions be-

2 tween lava and trees: The case of Kīlauea's July 1974

3 flow

4 Magdalena Oryaëlle Chevrel ${ }^{1} \bullet$ Andrew Harris $^{1} \bullet$ Alexian Ajas $^{1} \bullet$ Jonas Biren $^{1} \bullet$ Lucia Gurioli $^{1} \bullet$ Laura $^{2}$ 5 Calabro ${ }^{1}$

$6{ }^{1}$ Université Clermont Auvergne, CNRS, IRD, OPGC, Laboratoire Magmas et Volcans, F-

763000 Clermont-Ferrand, France

\begin{abstract}
8 Abstract
9 To examine whether there was any physical or thermal interaction between trees and lava 10 when a lava flow inundates a forest we studied the Kîlauea's July 1974 lava flow. We mapped 11 the location of 600 lava-trees and the lava type (pāhoehoe versus ' $a$ ' $\bar{a}$ ), and sampled an addi12 tional ten lava-trees for chemical and textural analysis to infer flow viscosity and dynamics. 13 The emplacement event lasted 3.5 hours and markers on the outer surface of the lava-trees 14 allowed us to define initial high effusion rate and velocity $\left(\sim 400 \mathrm{~m}^{3} / \mathrm{s}\right.$ and $\left.5-10 \mathrm{~m} / \mathrm{s}\right)$ that then 15 declined to $9 \mathrm{~m}^{3} / \mathrm{s}$ and $4 \mathrm{~m} / \mathrm{s}$ during a waning phase. We find that lava passing through the 16 forest underwent an initial cooling rate of $4{ }^{\circ} \mathrm{C} / \mathrm{km}$ which increased to $10^{\circ} \mathrm{C} / \mathrm{km}$ late in the 17 eruption. This is no different to cooling rates recorded at Kîlauea for tree-free cases. There 18 thus appears to be no effect on cooling for this case. The lava-trees did, though, form a net19 work of vertical cylinders obstacles and evidence for local diversion of flow lines are noticed. 20 However, this varies with lava type, as almost no lava-trees form in ' $a$ ' $\bar{a}$. We find a relation 21 between the percentage of ' $a$ ' $\bar{a}$ and the number of lava-trees per hectare. The pāhoehoe-' $a^{\prime} \bar{a}$ 22 transition for this flow occurs at a viscosity of $10^{3} \mathrm{~Pa}$ s and this appears to be a threshold be23 low which lava-trees can form so as to behave as a network of obstacles, and above which 24 they cannot.
\end{abstract}

Keywords: Lava-tree, lava channel, cooling rate, viscosity, pāhoehoe-'a'ā transition 


\section{Introduction}

Lava flow emplacement dynamics are controlled by extrinsic parameters (topography, nature of the substrate, effusion rate, total volume emitted) and intrinsic properties (composition, temperature, vesicularity, cooling rate) which together control the viscosity and velocity of the lava (e.g., Chevrel et al. 2013; Harris and Rowland, 2015; Kolzenburg et al. 2017; Rumpf et al. 2018). Under cooling-limited conditions (Pinkerton and Wilson 1988; Wilson and Head 1994), the run-out distance of a lava flow (i.e., the maximum length that can be reached at a given effusion rate) has typically been related to the rate of effusion (Walker 1973), to the total volume of material erupted (Malin 1980) and to rheological changes due to the heat loss (Pinkerton and Wilson 1994). The evolution of the surface morphology of a channel-fed lava flow system commonly changes from a pāhoehoe-dominated proximal zone, to a medial transition zone with the formation of lava channels, to a distal zone of ' $a$ ' $\bar{a}$ (Lipman and Banks 1987). The transition between pāhoehoe and a'a has been the focus of many studies and is thought to be caused by an increase in strain rate or by a change in lava rheological properties including higher viscosity, development of yield strength and disruption of the cooled surface (e.g., Peterson and Tilling 1980; Cashman et al. 1999; Sehlke et al. 2014). To characterise the changing properties that control lava down-flow behaviour, several techniques have been used. If the flow is active, lava properties may be directly measured in the field (Lipman and Banks 1987; Moore 1987; Crisp et al. 1994; James et al. 2007; Belousov and Belousova 2018). In the case of solidified flows, several studies have analysed the textural and chemical evolution of samples collected between the vent and the flow front to obtain down-flow thermal, textural and rheological evolution (e.g., (Soule et al. 2004; Riker et al. 2009; Chevrel et al. 2013; Robert et al. 2014; Castruccio and Contreras 2016). Other studies have modelled lava flows as function of cooling either with analogue materials (e.g., Hulme 1974; Sakimoto 
and Gregg 2001; Garel et al. 2014) or via numerical models (e.g., Crisp and Baloga 1994; Dragoni and Tallarico 1994; Harris and Rowland 2001; Bernabeu et al. 2016; Kelfoun and Vargas 2016).

The lava flow emplacement is also highly dependent on ground topography, substrate roughness (Rumpf et al. 2018) and encountered obstacles (Dietterich and Cashman 2014). Dietterich et al. (2015) examined how lava, using small basaltic flows created in the laboratory-effectively pouring molten basalt onto a synthetic topography — can be diverted by obstacles. Using the same method, Rumpf et al. (2018) showed that the higher the ground roughness the lower the flow front velocity. Computational simulations were also used by Chirico et al. (2009) and Scifoni et al. (2010) to examine the effect of barriers on flow paths. However, the dynamics of lava moving through forested areas remains rather unknown. Recently, Bernabeu et al. (2018) showed that a fluid moving through a grid of vertical cylindrical obstacles, as analogue for a lava flow inundating a dense forest, would form a wider and thicker flow than expected. Besides when the lava enter in contact with trees, energy will also be required to heat, dry and combust wood (e.g., Van Wagner 1967; Babrauskas 2002). These studies suggest that the presence of cold, combustible obstacles in the flow may be added to the list of extrinsic parameters that potentially affect lava flows. Trees may thus play a role in both thermally and mechanically interacting with the flowing lava to exert a control on lava flow rheology, and thus also dynamics and morphology, as well as path and dimensions. However, although several studies exist that describe the morphology of casts left by trees due to the quenching effect on lava flowing around them, i.e., lava-trees (e.g., Finch 1931; Moore and Richter 1962; Lockwood and Williams 1978; Carveni et al. 2011; Parcheta et al. 2012), no data are available on the effects of vegetation on lava flow propagation. There therefore remains an outstanding question: can trees cause enhanced lava cooling and mechanically interact with an advancing flow, thereby playing a role in changing flow dynamics 
and morphology (pāhoehoe versus 'a'ā) as compared with a forest-free scenario? To answer this question our study focuses on the July 19-22, 1974 lava flow of Kîlauea (Hawaii), a flow well-known for its abundance of standing lava-trees (Hazlett 1993). We carried out detailed mapping and analysis of glassy samples collected from the inside and outside surfaces of the lava-tree casts and extracted flow temperature, plus crystal and bubble concentrations at each sampled site. These results were then used to estimate down-flow cooling and infer the corresponding increase in viscosity, which - for this case - appears no different to a tree-free emplacement case. Our analysis does, however, imply that some local mechanical interactions do occur with lava-trees, and allows us to propose a conceptual model and a viscosity threshold at which a tree may or may not turn into a lava-tree, and hence can or cannot interact. This point corresponds with, but does not cause, the pāhoehoe-'a'ā transition.

\section{Lava-trees and tree-molds}

It is well known that when low viscosity pāhoehoe invades a forest, often the lava does not topple the trees but rather cools rapidly against the cold, damp bark to form a cast of the tree (Finch 1931; Jaggar 1945; MacDonald et al. 1983). Following Finch (1931), a tree inundated by lava will form a quenched cast of lava around it. The tree will then heat to combustion and burn slowly as the lava continues to flow around it (Honda 1998). If the lava level remains constant then, once the tree has burnt away, a "hollow cylinder" (Moore and Richter 1962) or "hole" (Finch 1931) will be left in the lava flow with the same size and form as the tree root, trunk and branch system. The texture of the bark is often imprinted onto the interior of the cast surrounding the hole, so this is termed a "tree-mold" (Finch 1931; Lockwood and Williams 1978). If the lava level subsequently drops, then the tree cast will instead be left standing as a column (Fig.1); this is a "lava-tree" (Finch 1931; MacDonald et al. 1983; Lockwood and Hazlett 2010). In this case, rapid lowering of the lava level may cause the crust to scrape across the plastic outer surface of the cast to cause striations and tension- 
102

103

104

105

produced gash fractures (Moore and Richter 1962). In some cases, the lava may entirely overcome the height of the tree to form a closed lava-tree (Moore and Richter 1962). Where the lava did not reach the top of the tree, the hole left by the consumed trunk is exposed forming an open lava-tree. In such a case, one can have access to pre-lava inundation ground surface through the shaft (Fig. 1). In some places, tree trunks inside the cast may not burn completely, indicating that the lava inundation and drainage must have taken place in a short time (Fiske and Koyanagi 1968); in others, the tree may be toppled and ingested horizontally into the lava or its crusts (basal or surface) to form horizontal, tubular molds (MacDonald et al. 1983; Carveni et al. 2011).

Lava-trees have been used in various ways, such as to estimate maximum thicknesses reached by a lava flow (Moore and Richter 1962; Moore and Kachadoorian 1980), to retrieve flow direction (Lockwood and Williams 1978), or to reconstruct the pre-eruption topography of the ground surface (Jones et al. 2017; Parcheta et al. 2012). Lava-trees have also been described as tools for "public educational purposes" (Carveni et al. 2011) and, given their narrow cave-like properties, been the focus of speleological studies (Bella and Gaál 2007). Additionally, charcoal left beneath a flow or in the tree molds (Searle 1958) can be analysed by $\mathrm{C}^{14}$ for dating lava flow emplacement (Kuntz et al. 1986).

All of these studies have described the tree-lava contact and the formation or structure of tree molds and lava-trees. However, no in-depth study exists on under which conditions lava-trees form and whether and how a forest might influence the emplacement dynamics and final form of a lava flow. Guest et al. (1987), Harris et al. (2017) and Bernabeu et al. (2018) have suggested that trees can act to, or at least participate in, slowing down the advance of a lava flow. In addition, Lockwood and Williams (1978) have shown that if two trees are sufficiently close, a chilled crust may form between the trunks to form a wall or barrier of solid lava 
127

128

129

130

131

132

133

134

135

136

137

138

139

140

141

142

143

144

145

146

147

148

149

150

151

The July 19, 1974 lava flow

Around 12:30 (Hawaiian Standard Time) on July 19, 1974, lava fountaining began from a small fissure at the base of the south wall of Keanakāko' $i$ pit crater; with a second fissure opening a few minutes later north of Keanakāko'i (Lockwood et al. 1999). Shortly thereafter, two en-echelon fissures appeared on the south-eastern sector of the caldera floor, feeding a pāhoehoe sheet flow eastward and northward across the caldera floor (Lockwood et al. 1999). Around the same time, the fissures extended through the Ōhi'a forest to the west of Keanakāko' $i$ to feed "a fast-moving fluid flow consisting of slabby pāhoehoe and 'a'a that travelled quickly to the south and southeast" for a distance of $2 \mathrm{~km}$ (Lockwood et al. 1999). By 13:00, lava from these fissures began to cascade into Keanakāko' $i$ to the north and Lua Manu craters to the east, forming a second, eastern, lava flow unit and cutting the chain of craters road (Fig. 2). Although the eruption continued until July 22, activity along the fissures to the east of Keanakāko'i ceased by 16:15 on July 19 (Lockwood et al. 1999), having lasted around three and a half hours. Soule et al. (2004) gives a volume for the south-eastern unit of $3.5 \times 10^{6} \mathrm{~m}^{3}$, for a mean output rate (given a 3-5 hour eruption duration) of $195-325 \mathrm{~m}^{3} / \mathrm{s}$ $\left(280 \mathrm{~m}^{3} / \mathrm{s}\right.$ for a 3.5 hour duration). It is the southeast lava flow of this fissure system on which we focus (Fig. 2).

This south-eastern lava flow formed a "field of lava-trees" (Lockwood et al. 1999), and Glatzer (1974) reports forest fires ignited by the passage of the lava, although these were "well under control by nightfall" on July 19. Instead, the "biggest headache" was "illegal parking (by sightseers) in the fire lanes", where "every possible place to park" was filled (Glatzer 1974). The damage caused to forest in this region due to the 1959 eruption of Kîlauea Iki and the 1974 eruption, as well as subsequent regeneration, has since been studied by Smathers and Mueller-Dombois (2007). The south-eastern lava flow is also the same flow as the one studied by Moore and Kachadoorian (1980) and Soule et al. (2004). Moore and 
152 Kachadoorian (1980) used the lava-trees to approximate the maximum flow depth and thereby

153 obtained maximum average flow velocities - $1.56 \mathrm{~m} / \mathrm{s}$ (near-vent) and $0.14 \mathrm{~m} / \mathrm{s}$ (distally) -

154 assuming a viscosity of around $2000 \mathrm{~Pa}$ s. Velocities and viscosities are also available from

155 features of super-elevation for a lava channel active during this eruption to the north of

156 Keanakāko'i where lava "raced down a curving gully, with lava banking up against and spray-

157 ing the outside of several bends" (Lockwood et al. 1999). In this channel, velocities were in

158 excess of $8 \mathrm{~m} / \mathrm{s}$ and viscosities were calculated by Heslop et al. (1989) as being 80-140 Pa s.

159 In contrast, Soule et al. (2004) examined the pāhoehoe-'a'ā transition in the south-eastern

160 flow, which they estimated occurred at a distance of $1.5 \mathrm{~km}$ from the vent. In the present

161 work, we examine whether the presence of trees affected downflow cooling, and hence rheo-

162 logical and dynamic changes in the channel-contained lava, as well as the relationship be-

163 tween the presence of lava-trees and the pāhoehoe-'a'ā transition.

\section{Methods}

165 Mapping and sampling

166 The lava flow area, surface morphology and lava-tree locations were mapped using digital

167 elevation model (DEM) with spatial resolution of $10 \mathrm{~m}$ and a vertical accuracy of $1-2 \mathrm{~m}$, as

168 derived from TOPSAR (topographic synthetic aperture radar) by Mouginis-Mark and Garbeil

169 (2005). The U.S. Geological Survey 7.5-minute (1:24,000-scale) topographic map sheet for

170 the Kîlauea Crater quadrangle (1981 edition) was also used to support mapping, along with

171 the cloud-free image satellite from GoogleEarth ${ }^{\mathrm{TM}}$ (image (C) 2018 DigitalGlobe -

$17201 / 30 / 2016$ ) in which individual lava-trees, as well as tree trunks lying on the flow surface,

173 can be discerned. Locations of all lava-trees were added as a layer, and the density of lava-

174 trees (number of lava-tree per unit area) was calculated from the number of objects within

175 200-m-long sectors along the length of the flow. The number of trees per unit area before the 
eruption was also estimated via counting treetops in areas of one hectare from an aerial image taken in 1965 (https://guides.library.manoa.hawaii.edu/aerials/digital - see online resource 1) and from an area aside of the flow using the GoogleEarth ${ }^{\mathrm{m}}$ (image (C) 2018 DigitalGlobe 01/30/2016).

Additionally, field mapping and sampling were carried out in November 2016. During field work, 35 lava-trees within $200 \mathrm{~m}$ from the vent were located with hand-held GPS (WGS84) and their dimensions measured. Measured dimensions are marked on Fig. 1c and included: the diameter of the central hole, the width of the ring of solid lava surrounding the central hole, the height of the lava-tree above the current surface, and the depth of the central hole (i.e., distance from the highest flow level to the pre-existing ground surface). In addition, two sets of samples were collected. The first set corresponds to the sampling of nine lavatrees - one lava-tree every $200 \mathrm{~m}$ along a straight line in the centre of the channel between the vent and the flow front (T1-T9, Fig. 2 and 3, Table 1), plus one lava sample located on the eruptive fissure itself (vent sample "V" in Fig. 2). This set of samples is used to study the lava chemical and textural variation down flow. The sampling involved the whole width of the cast at the top of the lava-tree, so that the hand sample included the cast surface that was in contact with the tree (hereafter called "tree-side") and the exterior of the cast that was in contact with the lava when it drained away (hereafter called "lava-side"). All dimensional measurements of Fig. 1c were also taken. Two to three thin sections were made from each lava-tree: one from the tree-side surface (hereafter labelled "-T"), a second from the lava-side surface (hereafter labelled "-L"), and — if possible — a third between the tree and lava sides (hereafter labelled "M"), for a total of 26 thin sections (Fig. 3). The second set of samples was collected on the lava side of a single tree (T10, Fig. 4) to observe the lava chemical and textural evolution from the bottom to the top of the lava-tree cast. This lava-tree (T10) was selected as it was one of the tallest $(1.92 \mathrm{~m})$ found during the down-flow sampling, and showed six level mark- 
201 ers where lava had remained at a stable level for a short period of time during waning flow.

202 One sample was taken from each level (Fig. 4).

203 Chemical and textural analyses

204 The dense rock equivalent (DRE) density was determined from powdered sample fragments 205 of known masses and using an Accupyc 1340 Helium Pycnometer that measured their vol206 umes. The bulk density of the samples was measured using an envelope density analyser (Mi207 cromeritics Geopyc 1360), which measures the difference in the volume of a quasi-fluid me208 dium with and without the sample embedded in that medium. As presented by Kawabata et al. 209 (2015) the Geopyc instrument can measure the envelope density of objects of different sizes 210 and shapes. Prior to immersion, samples were dried in an oven for 24 hours at a temperature 211 of $70{ }^{\circ} \mathrm{C}$ and then wrapped with thin laboratory parafilm ${ }^{\circledR}$, to preserve external irregularities 212 but to avoid the medium entering the porous sample. The standard deviation was estimated 213 from five measurements to be $\pm 30 \mathrm{~kg} / \mathrm{m}^{3}$ by Thivet (2016). The density-derived vesicularity 214 was then calculated using the relationship given by Houghton and Wilson (1989).

215 Bulk rock major element analysis of one sample was carried out with Inductively Cou216 pled Plasma - Atomic Emission Spectroscopy at the Laboratoire Magmas et Volcans (LMV, 217 Université Clermont-Auvergne, France). The chemical composition of the glass and minerals 218 were measured on polished thin sections via electronic microprobe CAMECA SX 100 (at 15 $219 \mathrm{kV}$ and a defocused beam of $20 \mu \mathrm{m}$ at a current of $8 \mathrm{nA}$ for glass and a focused beam at 15 $220 \mathrm{nA}$ for minerals). The temperature of lava during emplacement was obtained using the glass 221 composition through applying the MgO-glass geothermometer of Helz and Thornber (1987).

222 Backscattered electron (BSE) images were collected by scanning electron microscopy (SEM) 223 at magnifications of $25 \times$ and $100 \times$ and converted into binary images that were used for ex224 traction of vesicle size distribution (VSD). Following Shea et al. (2010), we considered only 225 vesicles that were larger than 10 pixels, which corresponds to an equivalent diameter of 0.05 
$\mathrm{mm}$. Crystal content in the glassy area of the thin section at the contact with the surface of the

tree side and lava side was estimated using two images per sample via ImageJ, considering only crystals larger than three pixels; that is, greater in length than $6 \mu \mathrm{m}$. The percentage of crystals was corrected for vesicularity and is therefore given for the vesicle-free mixture.

\section{Estimation of lava viscosity and flow velocity}

The viscosity of the three-phase lava mixture (fluid+crystals+bubbles) was estimated down the flow following the petrologic approach that considers the chemical, thermal and textural analyses of the samples (e.g., Pinkerton and Stevenson, 1992; Crisp et al. 1994; Guilbaud et al. 2007; Robert et al. 2014; Chevrel et al. 2013, 2018; Rhety et al. 2017). This method was applicable only to samples containing sufficiently large $\left(>1 \mathrm{~mm}^{2}\right)$ areas of glassy matrix where the composition of the quenched melt could be measured, temperature calculated and crystal content extracted. First the viscosity of the interstitial melt was calculated as a function of chemistry and temperature using the model of Giordano et al. (2008). Second, the effect of the crystal cargo on viscosity was estimated following the method described in Mader et al. (2013), which uses the equation of Maron and Pierce (1956) and considering a crystal maximum packing calculated using the average aspect ratio of the crystals (Mueller et al. 2010). We thereby obtained the vesicle-free mixture viscosity. Third, the effect of bubbles on the mixture viscosity was estimated from the vesicle fraction (obtained from the vesicularity derived from density) via the equation given by Llewellin and Manga (2005) for deformable bubbles. Using these viscosities, we calculated the instantaneous velocity of the lava with the Jeffreys equation (Jeffreys 1925). For this, we considered the maximum and final depths of the flow as measured on each sampled lava-trees and an average underlying slope. Error propagation analyses on the estimation of lava viscosity and flow velocity are detailed in online resource 2 . 


\section{Results}

The July 19, 1974 lava flow and its lava-trees

252 We measured a length for the south-eastern lava flow of the July 19 flow field of $2200 \mathrm{~m}$, 253 with the unit covering an area of $60.55 \times 10^{4} \mathrm{~m}^{2}$ in which a total of 598 lava-trees were mapped (Fig. 2). We note here that the flow generally contained lava-trees, and not treemolds, indicating a flow-wide lowering of the flow level as the eruption progressed. pāhoehoe sheet flow, proximal channel, medial channel, distal channel and distal dispersed ' $a$ 'a flow. Around the eruptive fissure, the lava is a smooth-surfaced "hummocky" (Swanson 1973) pāhoehoe sheet flow over a surface with a slope of less than $0.5^{\circ}$ (estimated from the lava flow surface). At $300 \mathrm{~m}$ from the fissure, multiple incipient channels arise within the pāhoehoe sheet flow. This is the zone of proximal channel which extends $200 \mathrm{~m}$ over a slope of $1.9^{\circ}$ and feeds into the medial channel section at a distance of $500 \mathrm{~m}$ from the vent. Here, channels become well-formed across a zone of slightly steeper slopes $\left(2.0^{\circ}\right)$ and the flow becomes concentrated in two 20-30 m-wide main channels. As noted by Soule et al. (2004), here the two channels bifurcate around a topographic high and form streams of ' $a$ ' $\bar{a}$ and thin, broken slabs of pāhoehoe surrounded by low initial levees of pāhoehoe; the channel margin is 267 commonly only marked by a line of shearing between the static levées and the moving lava 268 stream. At a distance of $900 \mathrm{~m}$, the two channels coalesce into a single, broad ( $\sim 50 \mathrm{~m}$ wide) and 500 m-long stream of ' $a$ 'ā and pāhoehoe slabs between broad initial levees of the same material. Down this distal channel section the slope is $0.75^{\circ}$ and, while the occurrence of co-

271 herent pāhoehoe slabs within the channel decreases with distance, the percentage of surface 272 area of ' $a$ ' $\bar{a}$ increases (Fig. 2). After a distance of 1450 m, flow is of entirely 'a'ā. The zone of 273 dispersed flow is 100 to $180 \mathrm{~m}$ wide, lies on a slope of $1.1^{\circ}$ and feeds two $70-90 \mathrm{~m}$-wide lobes with 2-3 m high flow fronts (Fig. 5). 

measured from the highest lava stand as given by the full lava-tree depth (i.e., value $D$ in Fig. 1c). Then, following Jones et al. (2017) the final, lowest level was obtained from subtracting 278 the lava-tree height above the current surface from the full lava-tree depth (i.e., value $F=D$ $279 H$ in Fig. 1c). In the near-vent zone, lava-tree depths were in the range 1.1-7.7 m, with a mean 280 of $3.2 \mathrm{~m}$ and a standard deviation of $1.3 \mathrm{~m}$ - this being the maximum flow level around the 281 vent. Heights above the 1974 surface were between 0.42 and $1.95 \mathrm{~m}(1.1 \pm 0.4 \mathrm{~m})$, giving a 282 final lava level of $0.5-6.5 \mathrm{~m}(2.1 \pm 1.1 \mathrm{~m})$. Down-flow, there was no systematic variation in 283 lava level (Fig. 3). However, maximum levels $(1.8-5.1 \mathrm{~m}, 1.9 \pm 0.7$, n. $=10)$, as well as min284 imum flow levels $(0.2-2.4 \mathrm{~m}, 1.2 \pm 0.7 \mathrm{~m}, \mathrm{n} .=10)$, were generally lower than around the 285 vent. These values compare with the maximum flow thicknesses of Moore and Kachadoorian (1980) of 2.0-5.2 $\mathrm{m}(3.8 \pm 1.1 \mathrm{~m}, \mathrm{n} .=6)$, and minimum thicknesses of $1.1-1.7 \mathrm{~m}(1.3 \pm 0.2$ $287 \mathrm{~m})$.

In terms of lava-tree density (Fig. 6), the proximal part of the lava flow contains the 289 highest concentration (20-30 lava-trees/ha), with more than half of the lava-trees being locat290 ed in the first $400 \mathrm{~m}$ near the vent (25\% of the flow area) where pāhoehoe sheet flow domi291 nated. As distance increases from the zone of pāhoehoe sheet flow, the density of lava-trees 292 steadily decreases as the proportion of ' $a$ ' $\bar{a}$ to pāhoehoe increases (Fig. 6). There is a complete 293 absence of lava-trees at the flow front, where 'a'a $\bar{a}$ is $100 \%$; and the last lava-tree is found 200 $294 \mathrm{~m}$ from the front. At the flow front, trees in the process of being bulldozed can be found top295 pled onto the flow surface.

296 Morphology and dimensions of lava-trees

297 Near the vent and in the zone of pāhoehoe-sheet flow the lava-trees are, for the most part, well 298 preserved. Most have conserved the initial tree trunk disposition of main trunk and branch 299 systems and are lava-trees "en bouquet"; that is, they form a tightly grouped but upward 
splaying system of trunks and branches (Fig. 7a). Others are lone standing pillars either closed

301 (Fig. 7b) or open (Fig. 7c) and are associated with the remnant (unburnt) trunks of the trees 302 responsible for the casts (Fig. 7c). The heights of the lava-trees measured from the pre-flow 303 surface to their top are between $1.1-7.7 \mathrm{~m}$ (in average $3.2 \pm 1.2 \mathrm{~m}, \mathrm{n} .=42$ ) and their casts 304 have widths in the range 4-20 cm $(10.12 \pm 3.12 \mathrm{~cm})$, with central hole (trunk) diameters of 6$30570 \mathrm{~cm}(23 \pm 11.5 \mathrm{~cm})$. On the tree side of the cast the surface is smooth and tree bark imprints are well preserved. The lava side is rough, often with tension gashes, sharks teeth and striations that can be tied to descending slabs of pāhoehoe (Fig. 7d). All of these features indicate that the outer surface of the cast was still sufficiently plastic to "take the impressions of the crust" (Moore and Richter, 1962) and to deform plastically (Nichols 1939). The descending pāhoehoe slabs remain in-place, surrounding the base of the lava-tree and uptilted towards the lava-tree and often forming a dome like structure around the lava-tree (Fig. 7e). also often observed. The lava-tree of Fig. 4 is a good example. It is $1.9 \mathrm{~m}$ high, has a perime-

314 ter of $2.1 \mathrm{~m}$, and is capped by a 20 -cm-wide ring of rough-surfaced glassy pāhoehoe blebs, 315 and has five level markers down the lava side of the cast. These markers are expressed as 316 aligned trains of glassy globules and up-flow accretions. Glassy globules are stretched down 317 flow $\left(150^{\circ}\right.$ ESE) and plunge downwards at $22-25^{\circ}$. This is much steeper than the ground 318 slope $\left(2^{\circ}\right)$, indicating rapid drainage in the down-flow direction. Up-flow accretions consist of 319 larger blebs of rough surfaced pāhoehoe that wrap around the cast in the down flow direction, 320 and have the same orientation and plunge as the trains of glassy globules (Fig. 4). This attests 321 to maintenance of the high stand for a period of time to build the accreted cap, followed by a rapid decline in flow level with a series of brief stands at a single level to build the train-and- 
324 be no more than an hour or two and with the transient declines and pauses being of the time 325 scale of minutes.

In some places lava-trees are grouped (Fig. 7f) including two to four trees located at 1 to 2 meters of each other. In such a case, lava-tree casts merge to form a wall-like or barrier328 like structure which can be aligned up or cross-flow (Fig. 7f). Their profiles are irregular with high points, marking the lava-trees, joined by lower ridges or "seams" (Lockwood and Williams 1978) of accreted lava that join the lava-tree group together.

Textural and thermal analyses

332 The texture of the rock is porphyritic with phenocrysts of olivine within a glassy to microcrys333 talline matrix. Phenocryst content is 3 vol. $\%$ and does not change down flow. Microlites $(<0.2$ $334 \mathrm{~mm}$ ) include olivine and plagioclase, and their content increases from 0.6 vol.\% near the vent 335 to 33.1 vol.\% near the front (Fig. 8 and 9, Table 2). This gives a crystallization rate of around 33615 vol.\% per kilometre. As shown by the detailed sampling of the lava-side cast of T10, the 337 microlite content appears to increase from 12 vol. $\%$ at the top of the lava-tree to 25 vol. $\%$ at 338 the bottom (Table 3; Fig. 4).

Density and vesicularity derived from density (using a DRE density of $3030 \mathrm{~kg} / \mathrm{m}^{3}$ ) 340 were in the range $1500-2000 \mathrm{~kg} / \mathrm{m}^{3}$ and $34-53$ vol. \%, respectively (Table 2, Fig. 10a). Only 341 the sample from the tree side of T9 (near the vent) is markedly different with a density of 760 $342 \mathrm{~kg} / \mathrm{m}^{3}$ and a vesicularity of $75 \mathrm{vol} . \%$, representing at-vent gas-rich lava. Thereafter, there is no 343 down-flow trend in vesicle content (Fig. 10a), but vesicularity of the lava next to the tree is 344 always greater than that in the middle of the cast, attesting to a decrease in the bubble content 345 of the erupted (and flowing) lava with time. The VSD analyses reveal that most samples con346 tain one vesicle population between 0.05 and $5 \mathrm{~mm}$, except T5-T that also comprises some 347 vesicles larger that $10 \mathrm{~mm}$ and T1-T that includes two populations (Fig. 10b). 
The chemical composition of the glassy matrix (online resource 3) decreases down

349 flow from an $\mathrm{Mg} \#$ of 36 at the vent to 28 near the flow front (at $1.9 \mathrm{~km}$ ). For the tree side, this 350 decrease in $\mathrm{Mg} \#$ translates to cooling from $1139 \pm 2{ }^{\circ} \mathrm{C}$ at the vent and $1132 \pm 5{ }^{\circ} \mathrm{C}$ at $1.9 \mathrm{~km}$.

351 For the lava side, we calculated cooling from $1140 \pm 2{ }^{\circ} \mathrm{C}$ to $1118 \pm 13{ }^{\circ} \mathrm{C}$. The temperature 352 decline estimated from the quenched lava against the tree is different to that for the lava side, 353 where there is a cooling rate of $4{ }^{\circ} \mathrm{C} / \mathrm{km}$ for initial lava quenched to the tree, and $10^{\circ} \mathrm{C} / \mathrm{km}$ for 354 late-stage lava accreted to the outer portion of the cast (Fig. 9). These straddle the average cooling rate of $6{ }^{\circ} \mathrm{C} / \mathrm{km}$ given for the same flow by Soule et al. (2004) but show a lower cooling rate during initial flow than during late-stage flow. From the sampling of the lava-side cast of $\mathrm{T} 10$, we see that the temperature may change by $2{ }^{\circ} \mathrm{C}$ from level to level, but there was no systematic variation with depth during drainage (Table 3, Fig. 4).

The viscosity of the melt phase varies down flow as glass composition evolves and tempera361 ture decreases, so that the melt viscosity increases from $470 \mathrm{~Pa} \mathrm{~s}$ at the vent to $700 \mathrm{~Pa}$ s distal362 ly. Including the effect of the crystal fraction and deformable bubbles (Table 4), the viscosity of the three-phase mixture was estimated at 90-190 Pa s near the vent (considering the conditions at T9: $1140{ }^{\circ} \mathrm{C}, 3.6-13.5$ vol.\% crystals and $46-75$ vol.\% elongated bubbles). These viscosities are in-line with those of Heslop et al. (1989) estimated from the super-elevation features in the near-vent channel active to the north of Keanakāko'i at the same time. Distally, 367 the three-phase viscosity is up to $3600 \mathrm{~Pa} \mathrm{~s}$ (considering the conditions at $\mathrm{T} 1: 1132{ }^{\circ} \mathrm{C}, 36$ 368 vol. \% crystals and 50 vol.\% bubbles). Our results give a viscosity ( $\eta$ in Pa s) with distance 369 (Dist in $\mathrm{m}$ ) trend of $\eta=160 \mathrm{e}^{0.0017 \mathrm{Dist}}$ with an $\mathrm{R}^{2}$ of 0.94 (Fig. 11a).

This viscosity variation has a direct influence on the flow velocity (Fig. 11). At vent, at 371 peak flow (maximum depth) velocities were as high as $9.8 \pm 2.6 \mathrm{~m} / \mathrm{s}$ (Table 4); similar to the 
maximum velocities obtained by Heslop et al. (1989) but higher than what estimated by Moore and Kachadoorian (1980). With distance down flow, the increase in viscosity causes the velocity to fall to $0.3 \pm 0.2 \mathrm{~m} / \mathrm{s}$ at $1915 \mathrm{~m}$. Declining output rate caused decreasing flow levels, so that the typical depth of late-stage flow near-vent $(1.2 \pm 0.7 \mathrm{~m})$ gives a lower final velocity of $0.2-4 \mathrm{~m} / \mathrm{s}$ at vent, waning to $0.04 \mathrm{~m} / \mathrm{s}$ at $1915 \mathrm{~m}$ (Table 4). Given channel width of $30 \mathrm{~m}$, the maximum flow depth and the final flow level measured at T5, this translates to a decrease in effusion rate from $403 \pm 250 \mathrm{~m}^{3} / \mathrm{s}$ to $15 \pm 9 \mathrm{~m}^{3} / \mathrm{s}$.

\section{Discussion}

Cooling effects of a forest

The 19 July 1974 lava flows advanced through a montane dry forest typical of Kîlauea's vegetation SW of Keanakāko‘i crater (Pratt and Gon III 1998). This zone receives less than $1000 \mathrm{~mm}$ of rain per year and experiences a dry season between mid-May and mid-October when rainfall is less than $100 \mathrm{~mm} /$ month (Smathers and Mueller-Dombois 2007). The dominant forest tree is the Ōhi'a (Pratt and Gon III 1998), a pioneer species native to Hawaii that forms "the canopy for virtually all Hawaiian forests" (Lincoln 2009). All lava-trees identified in this study were of Ōhi'a. In the zone where the fissures feeding the south-eastern flow of the 19 July eruptive activity broke out, we estimated the number of trees before the eruption at 55 to 95 per hectare. Giving the average trunk radii of $10.5 \mathrm{~cm}$ and a typical depth of $3.2 \mathrm{~m}$, this gives an area of $2.1 \mathrm{~m}^{2}$ of cold bark and a volume of $11 \mathrm{~m}^{3}$ of wood available to interact with the molten lava. The question is: are such tree densities, lava-tree contact areas and wood volumes sufficient to contribute a cooling effect to lava moving through the forest?

Lava flowing through the forest underwent an initial cooling rate of $4{ }^{\circ} \mathrm{C} / \mathrm{km}$ which increased to $10{ }^{\circ} \mathrm{C} / \mathrm{km}$ late in the eruption. This compares with cooling rates of $7{ }^{\circ} \mathrm{C} / \mathrm{km}$ estimated for this same lava flow by Soule et al. (2004) and for other lava flowing down channels 
in tree-free environments on Kîlauea and Mauna Loa (Crisp et al. 1994; Cashman et al. 1999;

397 Riker et al. 2009; Robert et al. 2014). Thus, the cooling rates appear normal, so there was no 398 discernible enhanced cooling effect due to the forest. The increase in cooling rate between the 399 beginning and end of the eruption was likely due to the decrease in velocity in the channels 400 with time as output rate feeding the channel system, and flow levels in the channels, declined. 401 Following Keszthelyi and Self (1998), a lower velocity flow will undergo a higher rate of 402 cooling per unit distance than a higher velocity flow. Simply, there is more time for lava mov403 ing at low velocity to cool as it passes from one location to the next than if it is moving at 404 higher speed (Harris and Rowland 2009). In our case, the increase in cooling rate is consistent 405 with a decrease in velocity in the proximal section (Tables 3 and 4).

The lack of a significant thermal interaction between the flowing lava and the trees,

407 and hence no enhanced cooling effect, could be due to three reasons. First, the casts would 408 have formed almost immediately and, as is the case for a tube roof (Keszthelyi 1995), would 409 have provided excellent thermal insulation to the lava flowing around the tree and thereby 410 isolating the tree from lava flowing down the channel. Second, the velocity of the lava (2-10 $411 \mathrm{~m} / \mathrm{s}$ ) and the small tree diameter (typically $0.2 \mathrm{~m}$ ) would have meant that the flowing lava 412 would have had a short interaction time (less than a tenth of a second) with the tree. Third, the 413 forest had suffered damage due to fall-out during the Kîlauea Iki eruption of 1959 so that, as 414 of 1962, the forest consisted of damaged Ōhi'a trees undergoing re-foliation, and lacked 415 dense, mature undergrowth (Smathers and Mueller-Dombois 2007). This, coupled with the 416 fact that the eruption occurred during the middle of the dry season, would have meant that the 417 moisture loads and vegetation densities would not have been as high as in a mature, undam418 aged forest. In the wet forest type that characterises the eastern edge of the flow and most of 419 Kīlauea's east rift zone (Pratt and Gon III 1998), vegetation and water would have been more 420 abundant still. Following Pratt and Gon III (1998), such zones consist of a closed-canopy (i.e., 
421 high density) of Ōhi'a with an understory of dense tree fern. The dominant fern is the Ciboti422 um species (Pratt and Gon III 1998), notably Hapu'u which can reach heights of 6-9 m, has 423 "loose, fibrous bark on their trunks" (Lincoln 2009) and large (2-4 m long) fonds (Merlin 424 2005) which are loaded with water. Finally, locally, trees quenched the lava to solidify a zone 425 of lava typically $10 \mathrm{~cm}$ wide. Considering the typical lava-tree height of $3.2 \mathrm{~m}$, the quenched 426 lava volume is $0.3 \mathrm{~m}^{3}$ per tree, and around $180 \mathrm{~m}^{3}$ within the flow. This volume is therefore 427 rather small in comparison to the volume of the entire flow $\left(3.5 \times 10^{6} \mathrm{~m}^{3}\right)$.

Mechanical interactions

429 The initial solidification of lava around the trees formed numerous lava-trees which remained 430 in place as vertical pillars and provided a series of obstacles around which the lava had to 431 pass. In the pāhoehoe sheet area of the flow, within $250 \mathrm{~m}$ of the fissure, about half of the 432 trees have been changed into lava-trees, while further down flow, where the lava is of a' $\bar{a}$ type, the lava destroyed all of the trees without creating any lava-trees. that lava did have to move around each lava-tree. Three cases of diversion can be identified (Fig. 12): scattered (isolated), cross-flow grouped, and down-flow grouped. In the isolated case, there is an exceedingly local effect where flow paths diverge around the pillar-like obstacle which is just $0.06-0.6 \mathrm{~m}$ wide. In the case of the cross-flow grouped lava-trees, we have a barrier that can be up to $5 \mathrm{~m}$ wide (Fig. 7f). This impedes flow, causing flow to move laterally as well as to back up behind the barrier to build accretions that pile up on the up-flow

441 side of the barrier. In the down-flow grouped case, a similar barrier to that formed in the 442 cross-flow case is formed, but because of its down-flow alignment it has less effect on flow 443 lines. However, the effect on diverging flow lines is greater than in the scattered case because 444 enhanced accretion around the lava-tree group causes the obstacle to be wider (1-2 m) than in the case of an isolated lava-tree. 

an obstacle. It therefore seems that although we find the trees did not affect thermally the lava, the lava-trees, once formed, act as a network of solid pillars or obstacles around which the

449 flow must move. Following Bernabeu et al. (2018) this can be viewed as a porous medium through which the fluid must move. The greater the number of lava-trees, the lower the porosity and hence the greater the effect on the dynamics for the fluid moving through the obstacle network. High obstacle densities cause the flow to be impeded and delayed, with the shape of the flow being changed (over the obstacle-free case), where fluid will spread and pile up in the porous zone (Bernabeu et al. 2018). Thus, a lava flow moving through a forest should be wider, thicker and shorter than for the same flow moving over a tree-free surface. This is also in agreement with previous observation of lava flows being thicker and slower where they branch or encounter obstacles (Dietterich and Cashman 2014). This effect on lava flow advance could also be compared with the recent study of Rumpf et al. (2018) where they find that flow front velocities are lower on rough terrain. However, they suggested that the slower 460 advance rate is due to enhanced cooling through the higher surface contact area of an irregular substrate. Here we suggest that the thermal effect caused by the contact with the trees might be rather trivial and that the mechanical effect caused by vertical obstacles might be the main factor affecting the flow advances rate.

Interaction of lava with a forest might therefore affect lava flow hazard assessment because of the potential mechanical effect of the trees once turned into lava-trees. Following Bernabeu et al. (2018), further modelling is necessary to quantify the effect of vertical pillars as local lava diverter or flow delaying mechanism. As argued by Dietterich et al. (2015), "mit468 igation of lava-flow hazards must incorporate the dynamics of lava flow-obstacle interactions 469 into barrier design". To go further, we suggest here that once and if the trees have been successfully transform into lava-trees, they may play the role of a "leaky" barrier (Dietterich and 
471 Cashman 2014). Growing well-designed forests between potential source vents and vulnera-

472 ble infrastructure may therefore offer a way to mitigate the risk caused by low viscosity lava 473 flows. However, experiments should be carried out to test if and how a dense forest would 474 affectively split the flow and slow down the advance. Scenarios including various types of 475 trees and different tree arrangements need to be designed and tested.

\section{Lava-trees and the pāhoehoe-' $\mathrm{a}^{6} \bar{a}$ transition}

477 There is a progressive down-flow transition from pāhoehoe to ' $a$ ' $\bar{a}$, beginning at a distance of 400-500 m from the vent, and is complete by a distance of $1500 \mathrm{~m}$ (Fig. 6). This is consistent with the findings of Soule et al. (2004) who found the pāhoehoe-'a'ā transition occurring in this flow between $500 \mathrm{~m}$ and $1500 \mathrm{~m}$. Soule et al. (2004) ascribed the transition to crystallini481 ty, with 'a'ā formation initiating when a critical crystallinity of 18 vol.\% was reached. Like482 wise, we find that this transition initiates at 15-20 vol. \%, which is the typical crystallinity 483 between $400 \mathrm{~m}$ and $1000 \mathrm{~m}$ (Fig. 9), and a viscosity of $10^{3} \mathrm{~Pa}$ (Fig. 11).

We also find a coincidence between the incidence of lava-tree formation and the pāhoehoe-'a'ā transition which progressively declines from 20-30 lava-trees per hectare in pure pāhoehoe to zero in pure 'a'ā (Fig. 6). However, this is the pāhoehoe-'a'ā transition in-

487 fluencing the process of tree-formation; and not vice-versa. Simply, fluid pāhoehoe can flow 488 between trees without toppling them, quenching to their trunks to allow lava-tree formation. 489 In contrast, 'a'ā bulldozes trees (as seen from the back-toppling cases at the flow front) 490 knocking them down so that they do not remain as vertical structures around which the lava 491 has to flow (Fig. 12). Thus, lava-tree formation (and flow impediment) is precluded. Instead, 492 trees topple onto the flow to be rafted down flow to eventually be heated and burnt on the 493 flow surface or rolled along in the basal clinker (Fig. 12). Thus, as lava progressively transi494 tions to ' $a$ ' $\bar{a}$ the incidence of lava-trees progressively declines. This decline follows a linear 495 relationship whereby the number of lava-trees of per hectare (NT) is related to the percentage 
496

497

of lava as pāhoehoe $(\mathrm{AA})$ through $\mathrm{NT}=-0.17(\mathrm{AA})+17\left(\mathrm{R}^{2}=0.7\right)$. Considering that the number of pre-existing tree per hectare is constant, this means that in the pāhoehoe sheet area of the flow, within the $150 \mathrm{~m}$ from the fissure, nearly all the trees have been changed into lava-trees, while further down flow, where the lava is of a'a type, all of the trees have been destroyed.

\section{Re-creating the emission history from a single lava-tree}

Using the level markers on lava-tree T10 we can recreate the emplacement history of the lava flow. Initial flow entered the channel (17.5 m wide) in which T10 resided at an effusion rate of $305 \mathrm{~m}^{3} / \mathrm{s}$ (Table 3 ). This is $75 \%$ of the value obtained for the single master channel at 920 $\mathrm{m}$ and into which this channel feeds (Table 4). Waning levels of flow in the channel reflected waning velocity and effusion rate, which dropped to a final value of $7 \mathrm{~m}^{3} / \mathrm{s}$. This is now around $50 \%$ of the value obtained for the master channel at the end of the eruption at $920 \mathrm{~m}$. Thus, it appears, the channel branch in which T10 resided took between 50 and $75 \%$ of the total lava flux.

The distribution of effusion rate $\left(E_{r}\right)$ with lava depth (D) shown in Table 3 has an exponential decaying form $\left(E_{r}=1.4 e^{1.87 D}, \mathrm{R}^{2}=0.97\right)$. If we distribute these effusion rates through time to fit to the total erupted volume $\left(3.5 \times 10^{6} \mathrm{~m}^{3}\right)$ and eruption duration $(3.5$ hours) this gives a function for the duration at which each level (\#) was maintained of duration $=3.5 e^{-693 \#}$. If we distribute the volume through time using this function we obtain the timings shown in Table 5. These timings suggest that peak flow was maintained the first half of the 3.5 hour-long eruptive period, with waning emission occurring over the second half. During waning, flow level (lava thickness) was maintained for an increasingly short period of time with shut down being abrupt. This is consistent with the observation by Lockwood et al. (1999) that "discharge rates at all fissures gradually began to decline" from around 2 hours 
520 after the eruption began, with all activity having ceased another one hour and 40 minutes lat521 er.

\section{Conclusion}

523 We studied the relationship between lava flow dynamics and lava-tree formation for the case 524 of the July 19, 1974 lava flow of Kîlauea. We mapped the lava flow morphology (pāhoehoe 525 vs. ' $a$ ' $\bar{a}$ ) and the distribution of lava-trees along the flow path. We found that lava-trees are 526 abundant (>20 lava-trees/ha) in the pāhoehoe area but sparse $(<5$ lava-trees/ha) in the 'a'a 527 section of the flow. We conclude that lava-trees can be formed when the lava flow is fluid 528 enough; in such a regime lava-trees can form in spite of high flow velocities $(\sim 10 \mathrm{~m} / \mathrm{s})$. How529 ever, when the lava becomes too viscous, a living tree will be overridden and no lava-tree can 530 be formed. This threshold occurs at a crystallinity of $15-20 \mathrm{vol} \%$ and viscosity of $10^{3} \mathrm{~Pa} \mathrm{~s}$ 531 where the pāhoehoe-' $a$ ‘'a transition takes place so that trees begin to be bulldozed by the ' $a$ ' $\bar{a}$

532 flow rather than flooded by pāhoehoe lava. If lava-trees form, markers on their outer surface 533 allow the eruption history to be recreated, which in this case involved 1.5 hours of high effu534 sion rate flow (at $\sim 400 \mathrm{~m}^{3} / \mathrm{s}$ ) followed by 1.5 hours of waning flow and abrupt shutdown. In this case, no enhanced cooling effect due to the presence of the trees was recorded,

536 but this may be a function of the rapidity of the inundation and the type of vegetation, which 537 was in poor health at the time of inundation. Mechanically, though, the lava was locally di538 verted by the array of solid cylinders formed by the lava-trees. Forests may thus have an ef539 fect in delaying flow advance and may be able to locally divert a flow from the expected path. 540 Further study on the effect of trees depending on their type will permit definition as to wheth541 er tree stands of certain types could be used, once turned into lava-trees, as local lava diverter 542 or flow delaying mechanism. Note, though, that if the lava is more viscous than a critical 
threshold, that is here given at $10^{3} \mathrm{~Pa} \mathrm{~s}$, lava-trees will not form. Further work in this direction

is clearly needed to assess the potential for vegetation barriers as a mitigation tool.

\section{Acknowledgements}

The authors gratefully acknowledge the support of Matthew Patrick, the Hawaiian Volcano Observatory and Hawaiian Volcanoes National Park where work was completed under National park permit HAVO-2016-SCI-0064. The pole technique of LMV (Christophe Constantin, Jean-Luc Devidal, JeanMarc Henot, Mhammed Benbakkar and Claire Fonquernie) is acknowledged for sample preparation and sam- ple analyses. Fieldwork was performed with the help of Scott Rowland and Alejandra Gomez-Ulla who are greatly acknowledged. Additionally, we thank Taeko Jane Takahashi at the HVO library for helping us track down the internal and newspaper reports for the events of 19 July 1974. Finally, T. Gregg, A. Soule (reviewers) and H. Dietterich (editor) are greatly acknowledged for their thorough reviews and comments, which improved the quality of this work.

\section{Funding information}

557 This research was financed by the Agence National de la Recherche through the project LAVA (Pro558 gram: DS0902 2016; Project: ANR-16 CE39-0009, http://www.agence-nationale-recherche.fr/ Projet559 ANR-16-CE39-0009). This is ANR-LAVA contribution no. 7. Fieldwork was supported by the Labor560 atory of Excellence ClerVolc program 6, contribution no. 316. MOC acknowledges the Auvergne 561 fellow-ship for support.

\section{References}

563 Babrauskas V (2002) Ignition of wood: a review of the state of the art. J Fire Prot Eng 12:163-189.

564 https://doi.org/10.1177/10423910260620482

Bella P, Gaál L (2007) Tree mould caves within the framework of cave genetic classification. Nat

566 Conserv 63:7-11

567 Belousov A, Belousova M (2018) Dynamics and viscosity of 'a'ā and pāhoehoe lava flows of the 568 2012-2013 eruption of Tolbachik volca- no, Kamchatka (Russia). Bull Volcanol 80:.

569 https://doi.org/10.1007/ s00445-017-1180-2

570 Bernabeu N, Saramito P, Harris AJL (2018) Laminar shallow viscoplastic fluid flowing through an 571 array of vertical obstacles. J Nonnewton Fluid Mech 257:59-70.

572 https://doi.org/10.1016/j.jnnfm.2018.04. 001

573 Bernabeu N, Saramito P, Smutek C (2016) Modelling lava flow advance using a shallow-depth approximation for three-dimensional cooling of viscoplastic flows. Geol Soc Lond Spec Publ 426:409423. https://doi.org/10.1144/SP426.27 stones ${ }^{\wedge}$ ) of Mt. Etna. 633-638. https:// doi.org/10.1007/s00445-011-0446-3 
Castruccio A, Contreras MA (2016) The influence of effusion rate and rheology on lava flow dynamics and morphology: a case study from the 1971 and 1988-1990 eruptions at Villarrica and Lonquimay vol- canoes, Southern Andes of Chile. J Volcanol Geotherm Res 327: 469-483. https://doi.org/10.1016/j.jvolgeores.2016.09.015

Chevrel MO, Harris AJL, James MR, Calabrò L, Gurioli L, Pinkerton H (2018) The viscosity of pāhoehoe lava: in situ syn-eruptive measure- ments from Kilauea, Hawaii. Earth Planet Sci Lett 493:161-171. https://doi.org/10.1016/j.eps1.2018.04.028

Chevrel MO, Platz T, Hauber E, Baratoux D, Lavallée Y, Dingwell DB (2013) Lava flow rheology: a comparison of morphological and petrological methods. Earth Planet Sci Lett 384:102-120. https:// doi.org/10.1016/j.eps1.2013.09.022

Chirico GD, Favalli M, Papale P, Boschi E, Pareschi MT, Mamou-Mani A (2009) Lava flow hazard at Nyiragongo volcano, DRC 2 Hazard reduction in urban areas. Bull Volcanol 71:375-387. https://doi.org/ 10.1007/s00445-008-0232-z

Crisp J, Baloga S (1994) Influence of crystallization and entrainment of cooler material on the emplacement of basaltic 'a'a lava flows. J Geophys Res 99:11,819-11,831. https://doi.org/10.1029/ 94JB00134

Crisp J, Cashman KV, Bonini JA, Hougen SB, Pieri DC (1994) Crystallization history of the 1984 Mauna Loa lava flow. J Geophys Res 99:7177-7198. https://doi.org/10.1029/93JB02973

Dietterich HR, Cashman KV (2014) Channel networks within lava flows: formation, evolution, and implications for flow behavior. J Geophys Res Earth Surf 119:1704-1724. https://doi.org/10.1002/ 2014JF003103

Dietterich HR, Cashman KV, Rust AC, Lev E (2015) Diverting lava flows in the lab. Nat Geosci 8:810. https://doi.org/10.1038/ ngeo2470

Dragoni M, Tallarico A (1994) The effect of crystallization on the rheol- ogy and dynamics of lava flows. J Volcanol Geotherm Res 59:241-252. https://doi.org/10.1016/0377-0273(94)90098-1

Finch R (1931) Lava tree casts and tree molds. Geol Soc Am Bull 442: 299

Fiske RS, Koyanagi RY (1968) The December 1965 eruption of Kilauea Volcano, Hawaii. US Geol Surv Prof Pap 607:21

Garel F, Kaminski E, Tait S, Limare A (2014) An analogue study of the influence of solidification on the advance and surface thermal sig- nature of lava flows. Earth Planet Sci Lett 396:46-55. https://doi. org/10.1016/j.epsl.2014.03.061

Giordano D, Russell JK, Dingwell DB (2008) Viscosity of magmatic liquids: a model. Earth Planet Sci Lett 271:123-134. https://doi. org/10.1016/j.eps1.2008.03.038

\section{Glatzer H (1974) Spectacular show at summit. In: Hawaii Trib Her. 20 July 1974. p. 5}

Guest JE, Kilburn CRJ, Pinkerton H, Duncan A (1987) The evolution of flow fields: observations of the 1981 and 1983 eruptions of Mount Etna, Sicily. Bull Volcanol 49:527-540.

https://doi.org/10.1007/ BF01080447

Guilbaud MN, Blake S, Thordarson T, Self S (2007) Role of Syn-eruptive cooling and degassing on textures of lavas from the AD 1783-1784 Laki eruption, South Iceland. J Petrol 48:1265-1294. 
https://doi.org/ 10.1093/petrology/egm017

Harris AJL, Rowland SK (2015) Lava flows and rheology. Encycl Volcanoes, 2nd Ed Eds Sigurdsson H, Hought B, McNutt SR, Rymer H, Styx J

Harris AJL, Rowland SK (2001) FLOWGO: a kinematic thermo- rheological model for lava flowing in a channel. Bull Volcanol 63: 20-44. https://doi.org/10.1007/s004450000120

Harris AJL, Rowland SK (2009) Effusion rate controls on lava flow length and the role of heat loss: a review. Leg Georg PL Walker, Spec Publ IAVCEI Eds Hoskuldsson A, Thordarson T, Larsen G, Self S, Rowl S Geol Soc London 2:33-51

Harris AJL, Villeneuve N, Di Muro A et al (2017) Effusive crises at Piton de la Fournaise 2014-2015: a review of a multi-national response model. J Appl Volcanol 6:11. https://doi.org/10.1186/s13617017- 0062-9

Hazlett RW (1993) Geological field guide at Kilauea Volcano. Hawaii Natural History Association, Honolulu, Hawaii, 127 p.

Helz RT, Thornber CR (1987) Geothermometry of Kilauea Iki lava lake, Hawaii. Bull Volcanol 49:651-668. https://doi.org/10.1007/ BF01080357

Heslop SE, Wilson L, Pinkerton H, Head JW (1989) Dynamics of a confined lava flow on Kilauea Volcano, Hawaii. Bull Volcanol 51: 415-432. https://doi.org/10.1007/BF01078809

Honda T (1998) Physico-chemical explanation for remeleting process of inner surface wall of Tainai tree molds located on the flank of Mt. Fuji. J Speleol Soc Japan 23:29-38. https://ci.nii.ac.jp/naid/ 10027009711/en/

Houghton BF, Wilson CJN (1989) A vesicularity index for pyroclastic deposits. Bull Volcanol 51:451-462. https://doi.org/10.1007/ BF01078811

Hulme G (1974) The interpretation of lava flow morphology. Geophys J R Astron Soc 39:361-383. https://doi.org/10.1111/j.1365-246X. 1974.tb05460.x

Jaggar TA (1945) Volcanoes declare war: logistics and strategy of Pacific volcano science. Honolulu, Hawaii. Paradise of the Pacific, Ltd., 166 p

James MR, Pinkerton H, Robson S (2007) Image-based measurement of flux variation in distal regions of active lava flows. Geochem. Geophys. Geosys. 8, Q03006. https://doi.org/10.1029/2006GC001448

Jeffreys H (1925) The flow of water in an inclined channel of rectangular section. Philos Mag serie 6(4):293,793-293,807

Jones TJ, Llewellin EW, Houghton BF, Brown RJ (2017) Proximal lava drainage controls on basaltic fissure eruption dynamics. Bull Volcanol 79:81. https://doi.org/10.1007/s00445-017-1164-2

Kawabata E, Cronin SJ, Bebbington MS, Moufti MRH, El-Masry N, Wang T (2015) Identifying multiple eruption phases from a com- pound tephra blanket: an example of the AD1256 Al-Madinah eruption, Saudi Arabia. Bull Volcanol 77:6. https://doi.org/10.1007/ s00445-014-0890-y

Kelfoun K, Vargas SV (2016) VolcFlow capabilities and potential devel- opment for the simulation of lava flows. In: Harris AJL, De Groeve T, Garel F, Carn SA (eds) Detecting, Modelling and Responding to Effusive Eruptions. Geological Society, London, pp 337-343 
Keszthelyi L (1995) Measurements of the cooling at the base of pahoehoe flows. Geophys Res Lett 22:2195-2198. https://doi.org/10.1029/ 95GL01812

660 Keszthelyi L, Self S (1998) Some physical requirements for the emplace- ment of long basaltic lava 661 flows. J Geophys Res B 11:27,447-27, 464. https://doi.org/10.1029/98JB00606

662 Kolzenburg S, Giordano D, Thordarson T, Hoskuldsson A, Dingwell DB (2017) The rheological evo663 lution of the 2014/2015 eruption at Holuhraun, Central Iceland. Bull Volcanol 79:45. https://doi.org/ 664 10.1007/s00445-017-1128-6

665 Kuntz MA, Spiker EC, Rubin M, Champion DE, Lefebvre RH (1986) Radiocarbon studies of latest 666 Pleistocene and Holocene lava flows of the Snake River Plain, Idaho: data, lessons, interpretations.

667 Quat Res 25:163-176. https://doi.org/10.1016/0033-5894(86)90054-2

668 Lincoln NK (2009) Amy Greenwell Garden Ethnobotanical Guide to Native Hawaiian plants \& Polynesian-introduced plants. Bishop museum press, Honolulu, Hawaii, p 135

670 Lipman PW, Banks NG (1987) Aa flow dynamics, Mauna Loa 1984. US Geol Surv Prof Pap $671 \quad 1350: 1527-1567$

672 Llewellin EW, Manga M (2005) Bubble suspension rheology and impli- cations for conduit flow. J

673 Volcanol Geotherm Res 143:205-217. https://doi.org/10.1016/j.jvolgeores.2004.09.018

674 Lockwood JP, Hazlett RW (2010) Volcanoes global perspectives. Wiley- Blackwell. Chichester, Unit675 ed Kingdom, p 539

Lockwood JP, Tilling RI, Holcomb RT, Klein F, Okamura AT, Peterson DW (1999) Magma migration and resupply during the 1974 summit eruptions of Kilauea volcano, Hawai'i. US Geol Surv Prof Pap 1613(37)

Lockwood JP, Williams IS (1978) Lava trees and tree moulds as indica- tors of lava flow direction. Geol. Mag. 115:69-74. https://doi.org/ 10.1017/S0016756800041005

MacDonald GA, Abbott AT, Peterson FL (1983) Volcanoes and the sea - The geology of Hawaii. University of Hawaii Press, Honolulu, Hawaii, p 517

Mader HM, Llewellin EW, Mueller SP (2013) The rheology of two-phase magmas: a review and analysis. J Volcanol Geotherm Res 257:135- 158. https://doi.org/10.1016/j.jvolgeores.2013.02.014

Malin MC (1980) Lengths of Hawaiian lava flows. Geology 8:306- 308. https://doi.org/10.1130/00917613

Maron SH, Pierce PE (1956) Application of Ree-Eyring generalized flow theory to suspensions of spherical particles. J Colloid Sci 11:80-95. https://doi.org/10.1016/0095-8522(56)90023-X

Merlin M (1995) Hawaiian forest plants. Pacific guide books, Honolulu, Hawaii. 80 p.

Moore HJ (1987) Preliminary estimates of the rheological properties of 1984 Mauna Loa Lava. US Geol Surv Prof Pap 1350(99):1569- 1588

Moore HJ, Kachadoorian R (1980) Estimates of lava-flow velocities using lava trees. Reports Plan Geol Prog 1979-1980:201-203 Moore JG, Richter DH (1962) Lava tree molds of the September 1961 eruption, Kilauea volcano, Hawaii. Geol Soc Am Bull 73:1153- 1158. https://doi.org/10.1130/0016- 
696 Mouginis-mark PJ, Garbeil H (2005) Quality of TOPSAR topographic data for volcanology studies at

697 Kilauea Volcano, Hawaii: an assess- ment using airborne lidar data. Remote Sensing of Environment

698 96: 149-164. https://doi.org/10.1016/j.rse.2005.01.017

699 Mueller S, Llewellin EW, Mader HM (2010) The rheology of suspen- sions of solid particles. Philos

700 Trans R Soc Lond A 466:1201-1228. https://doi.org/10.1098/rspa.2009.0445

701 Nichols RL (1939) Superficial banding and shark's-touth projections in the cracks of basaltic lava.

702 Amer 237:188-194. https://doi.org/10.2475/ajs.237.3.188

703

704

705

Parcheta CE, Houghton BF, Swanson DA (2012) Hawaiian fissure foun- tains 1: decoding depositsepisode 1 of the 1969-1974 Mauna Ulu eruption. Bull Volcanol 74:1729-1743.

https://doi.org/10.1007/ s00445-012-0621-1

Peterson DW, Tilling RI (1980) Transition of basaltic lava from pāhoehoe to 'a' $\bar{a}$, Kilauea volcano, Hawaii: field observations and key factors. J Volcanol Geotherm Res 7:271-293. https://doi.org/10.1016/0377- 0273(80)90033-5

Pinkerton H, Stevenson RJ (1992) Methods of determining the rheolog- ical properties of magmas at sub-liquidus temperatures. J Volcanol Geotherm Res 53:47-66. https://doi.org/10.1016/0377-0273(92) 90073-M

Pinkerton H, Wilson L (1988) The lengths of lava flows. Lunar Planet Sci. Abstr., XIX. pp 937-938

Pinkerton H, Wilson L (1994) Factor controlling the lengths of channel- fed lava flows. Bull Volcanol 6:108-120. https://doi.org/10.1007/ BF00304106

Pratt L, Gon SM III (1998) Terrestrial ecosystems. In: Atlas of Hawaii. University of Hawaii Press, Honolulu, Hawaii, pp 121-129

Rhéty M, Harris A, Villeneuve N, Gurioli L, Médard E, Chevrel O, Bachélery P (2017) A comparison of cooling-limited and volume-limited flow systems: Examples from channels in the Piton de la Fournaise April 2007 lava-flow field, Geochem Geophys Geosyst 18 https://doi.org/10.1002/2017GC006839

Riker JM, Cashman KV, Kauahikaua JP, Montierth CM (2009) The length of channelised lava flows: insight from the 1859 eruption of Mauna Loa Volcano, Hawaii. J Volcanol Geotherm Res 183:139156. https://doi.org/10.1016/j.jvolgeores.2009.03.002

Robert B, Harris A, Gurioli G, Medard E, Sehlke A, Whittington A (2014) Textural and rheological evolution of basalt flowing down a lava channel. Bull Volcanol 76:824. https://doi.org/10.1007/ s00445-014-0824-8

Rumpf ME, Lev E, Wysocki R (2018) The influence of topographic roughness on lava flow emplacement. Bull Volcanol 80:63.https:// doi.org/10.1007/s00445-018-1238-9

Sakimoto SEH, Gregg TKP (2001) Channeled flow: analytic solutions, laboratory experiments, and applications to lava flows. J Geophys Res 106:8629-8644. https://doi.org/10.1029/2000JB900384

Scifoni S, Coltelli M, Marsella M, Proietti C, Napoleoni Q, Vicari A, Del Negro C (2010) Mitigation of lava flow invasion hazard through optimized barrier configuration aided by numerical simulation: the case of the 2001 Etna eruption. J Volcanol Geotherm Res 192:16- 26. 
Searle EJ (1958) A note on the formation of native iron and other effects associated with contact of

736 basalt and carbonized wood at Auckland, New Zealand. New Zeal J Geol Geophys 1:451-458

Sehlke A, Whittington A, Robert B, Harris AJL, Gurioli L, Médard E (2014) Pahoehoe to 'a'a transition of Hawaiian lavas: an experimental study. Bull Volcanol 76:876. https://doi.org/10.1007/s00445014-0876-9

Shea T, Houghton BF, Gurioli L, Cashman KV, Hammer JE, Hobden BJ (2010) Textural studies of vesicles in volcanic rocks: an integrated methodology. J Volcanol Geotherm Res 190:271-289. https://doi. org/10.1016/j.jvolgeores.2009.12.003 141

Soule SA, Cashman KV, Kauahikaua JP (2004) Examining flow em- placement through the surface 66:1-14. https://doi.org/10.1007/s00445-003-0291-0

Swanson DA (1973) Pāhoehoe flows from the 1969-1971 Mauna Ulu eruption, Kīlauea volcano, Hawaii. Bull Geol Soc Am 84:615-626. https://doi.org/10.1130/0016-7606

Thivet S (2016) Caractérisation magmatique du système superficiel du Piton de la Fournaise à travers

Van Wagner CE (1967) Calculations on forest fire spread by flame radiation. Government of Canada, Department of Forestry and Rural Development, Petawawa Forest Experiment Station, Chalk River,

754 Ontario. Departmental publication 1185. 18 p.

755 Wilson L, Head JW (1994) Mars review and analysis of volcanic eruption theory and relationships to observed landforms. Rev Geophys 32: 221-263. https://doi.org/10.1029/94RG01113

\section{Figure captions}

759 Figure 1: Lava-tree formation (modified from Lockwood and Hazlett, 2010). a) Pristine forest

760 contains trees of various sizes and heights. b) When lava is in contact with air or with cooler

761 surfaces (ground and vertical obstacles like trees) it rapidly quenches and forms a chilled crust

762 (black) surrounding the hot, fluid interior (orange), and vegetation dries and burns. c) Lava

763 drains away, causing the subsidence of the flow surface and leaving behind standing lava-tree

764 casts and a dead forest. Measured lava tree dimensions are given in c. 
Figure 2: Map of the south-eastern July 1974 lava flow showing the studied unit and location

767 of samples and lava-trees (background of GoogleEarth image (C) 2018 DigitalGlobe). Inset

768 map showing the location of the studied lava flow, modified from Lockwood et al. (1999).

769 Lava-trees (black points) were located based on aerial photography, TOPSAR images and ground truthing. "Sampled lava-trees" indicates location were rock samples were taken (T1 to 771 T10; Table 1); "V" is the location of a sample taken at the vent.

Figure 3: Sampling methodology along the lava flow and thin section positions on lava-tree casts. Yellow dots indicate the presence of glassy matrix in the thin section.

Figure 4: Sampling of a single lava-tree (T10). From left to right: photo of T10 with location of samples) from top to bottom (labeled from A to G); sketch of the main features and dimensions, and variation of temperature (circles) and crystallinity (squares) as function the height.

Figure 5: Evolution of width (empty circles) and thickness (full circles) of the studied lava

781 flow as function of distance from the vent. Vertical dashed lines and numbers outline the five zones of the lava flow morphology: 1) near-vent pāhoehoe sheet flow; 2) proximal channel 783 area with multiple incipient channels; 3) well-formed channel that divided in two main chan784 nels; 4) coalescence into a single broad channel made of ' $a$ ' $\bar{a}$ and pāhoehoe slabs between 785 broad initial levées; 5) dispersed 'a‘ā flow.

787 Figure 6: Number of lava-trees per hectare and percentage of lava type (pāhoehoe vs. 'a'ā) 788 down flow. 
Figure 7: Examples of lava-tree morphologies: a) lava-trees "en bouquet" near the vent; b)

791 vertical closed lava-tree; c) open lava-tree with remaining dead tree; d) scratching of the plas792 tic outer surface of the cast causing striations and tension gashes; e) uptilted pāhoehoe slabs 793 remaining in-place surrounding the base of a lava-tree, forming a dome like structure; f) barri794 er made by accretion around and between two lava-trees.

795

796 Figure 8: SEM images of the matrix crystallization down flow.

797

798 Figure 9: Down flow variations in the temperature obtained from the glassy matrix on the lava 799 side (open circles) and on the tree side (full circles) of each sample, and crystal content in800 cluding phenocrysts + microlites (squares). Linear regression lines indicate $10^{\circ} \mathrm{C} / \mathrm{km}$ on the 801 lava side $\left(\mathrm{R}^{2}=0.78\right)$ and $4{ }^{\circ} \mathrm{C} / \mathrm{km}$ on the tree side $\left(\mathrm{R}^{2}=0.60\right)$. The temperature gradient from 802 Soule et al. (2004) is also reported for comparison $\left(7^{\circ} \mathrm{C} / \mathrm{km} \mathrm{R}^{2}=0.71\right)$. The linear regression 803 for the crystallinity indicates $16.2 \mathrm{vol} . \% / \mathrm{km}\left(\mathrm{R}^{2}=0.9\right)$.

804

805 Figure 10: a) Down flow variation of the vesicularity derived from density; b) Cumulative 806 vesicle number density plot considering the vesicle number density per volume in $\mathrm{mm}^{-3}(\mathrm{Nv})$ 807 with diameter greater than $\mathrm{L}$ (the equivalent diameter of the vesicle).

808

809 Figure 11: a) Down flow variation in the velocity (diamonds) and viscosity (crosses). The 810 black diamonds are our calculations and the open diamonds are the estimations given by 811 Moore and Kachadorian (1980); b) Velocity (diamonds) and viscosity (crosses) calculated 812 with flow depth around T10.

814 Figure 12: Conceptual model for the interaction of lava and trees depending on the lava type. 


\section{Table captions}

817 Table 1: Sample location and description

818 Table 2: Textural analyses down the flow

819 Table 3: Textural analyses and viscosity estimation along a single tree (T10)

820 Table 4: Viscosity and velocity estimation along the flow

821 Table 5: Reconstruction of the effusion rate history

822 


\section{Figure 1}

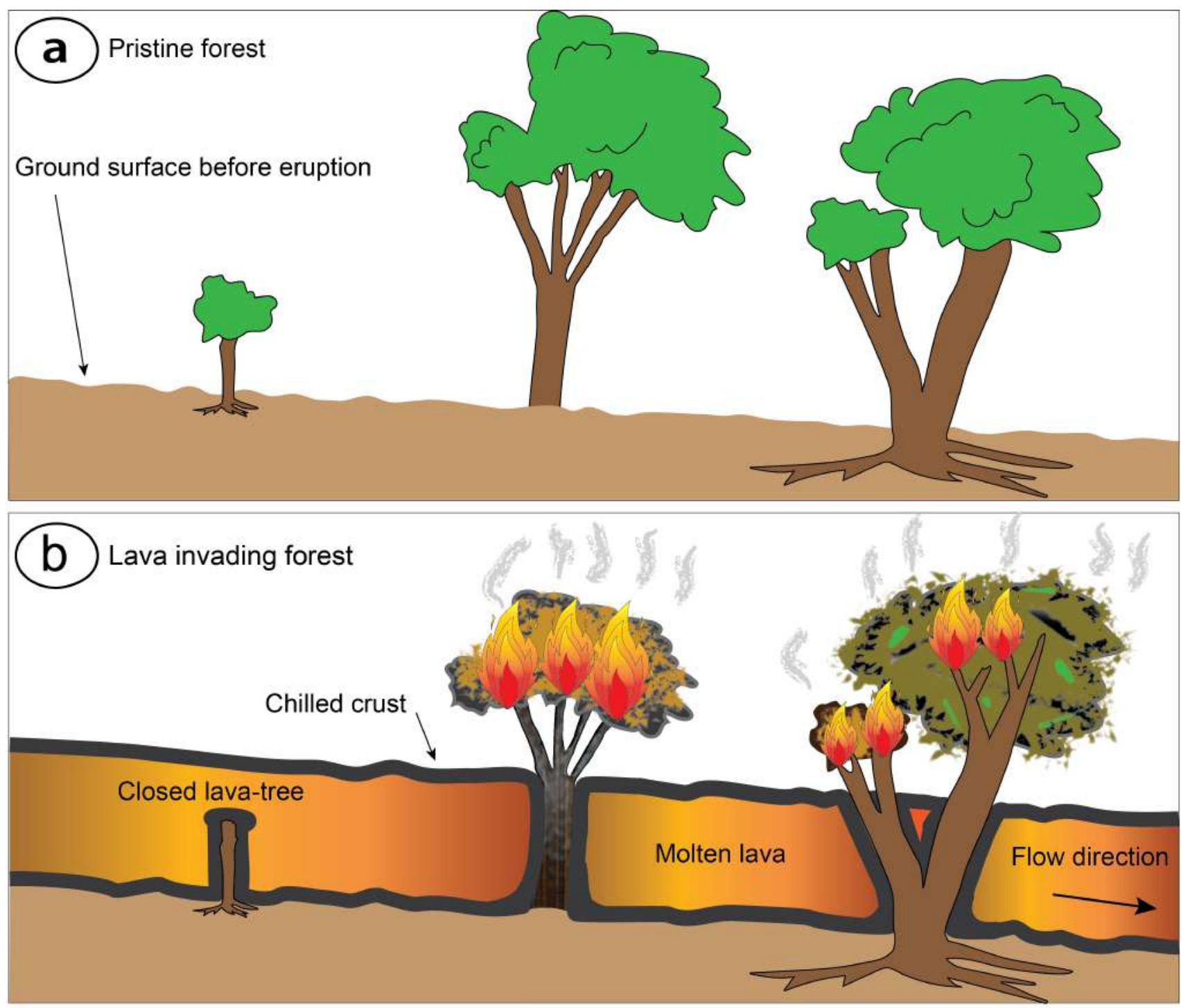

(C) Lava drainage \& lava tree formation

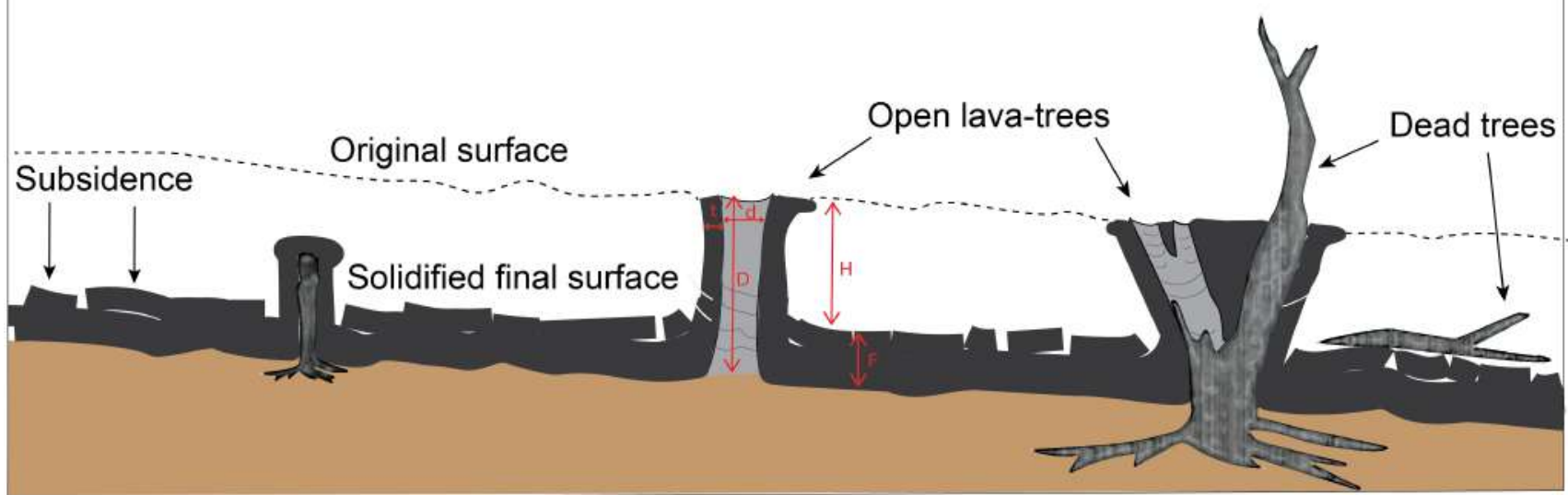


Figure 2

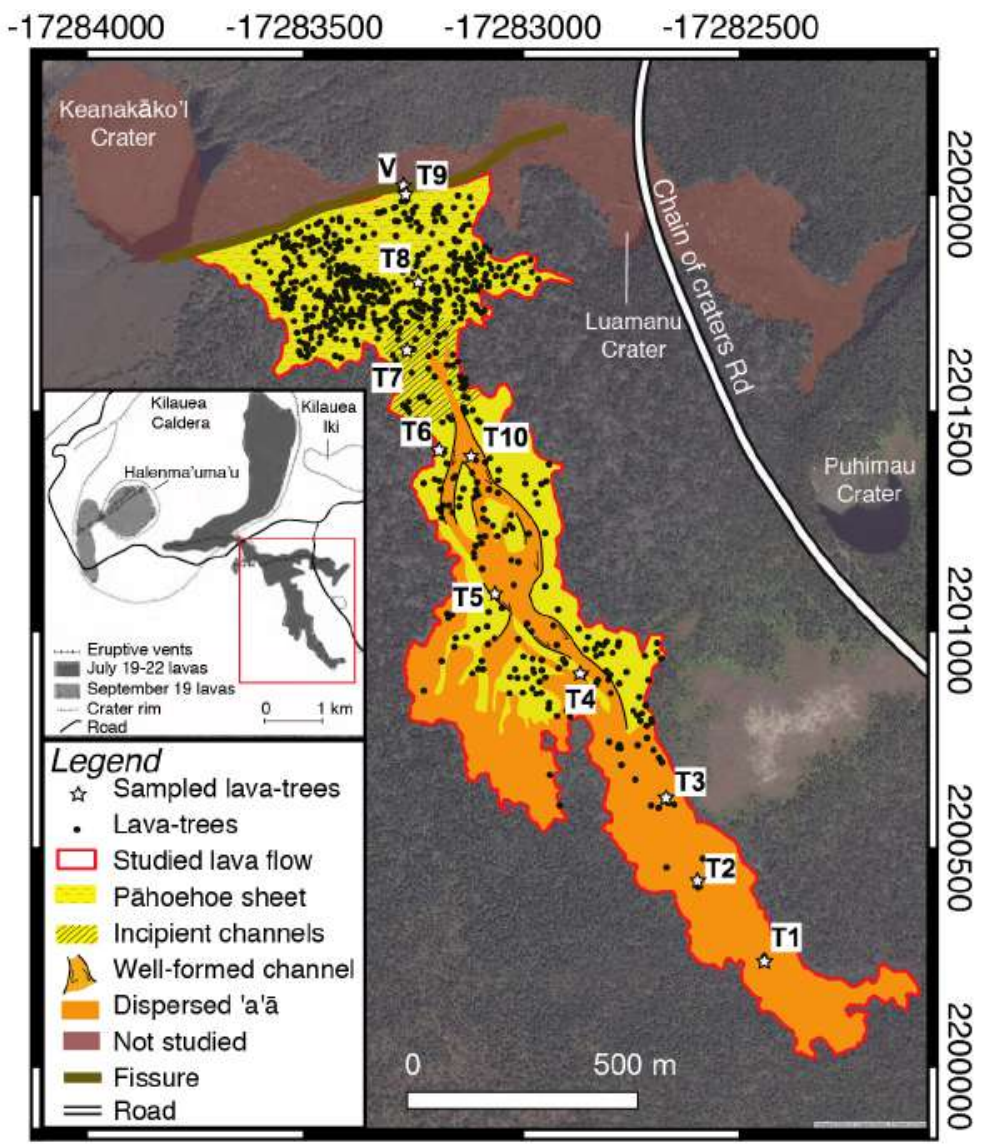


Figure 3

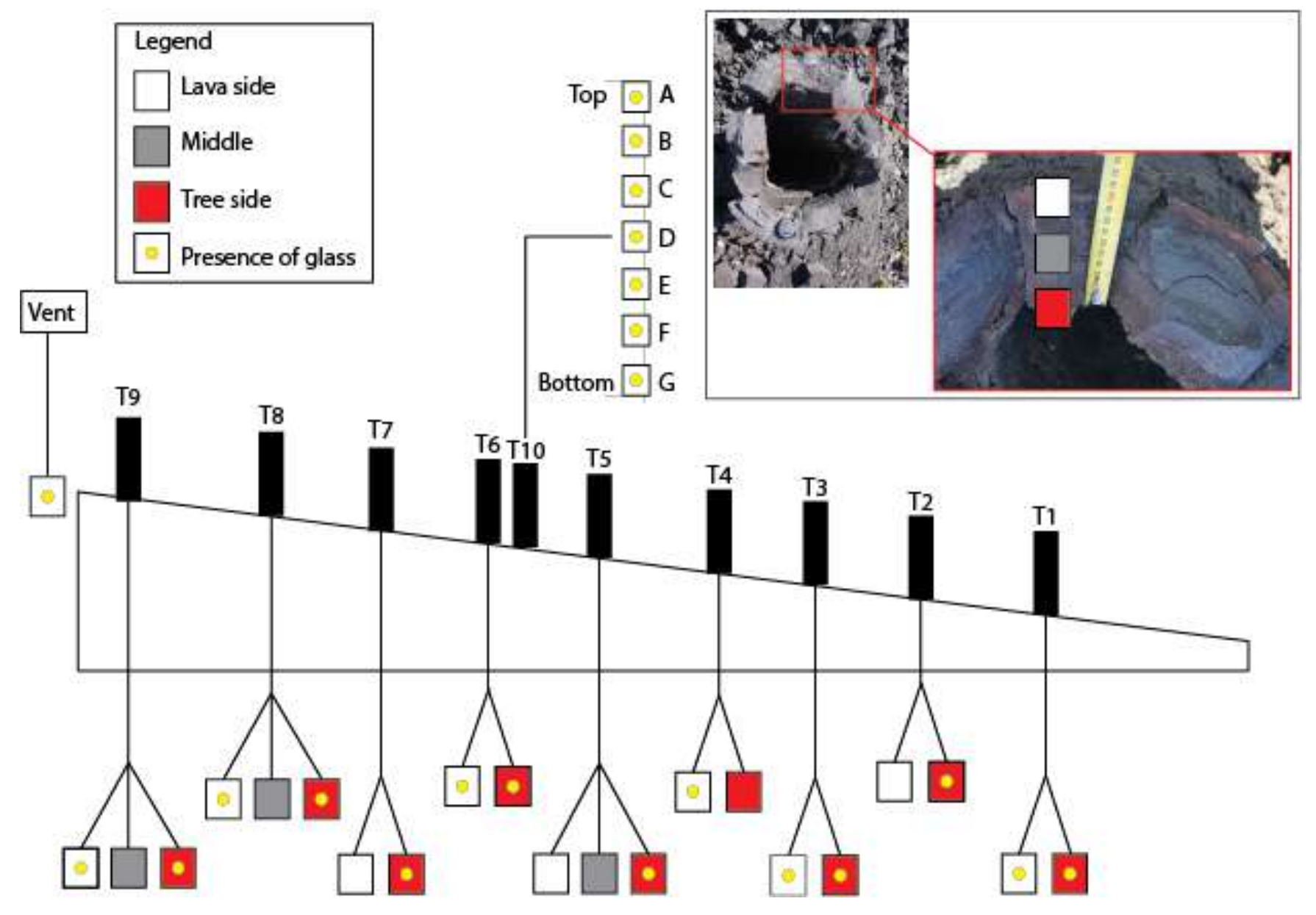


Figure 4

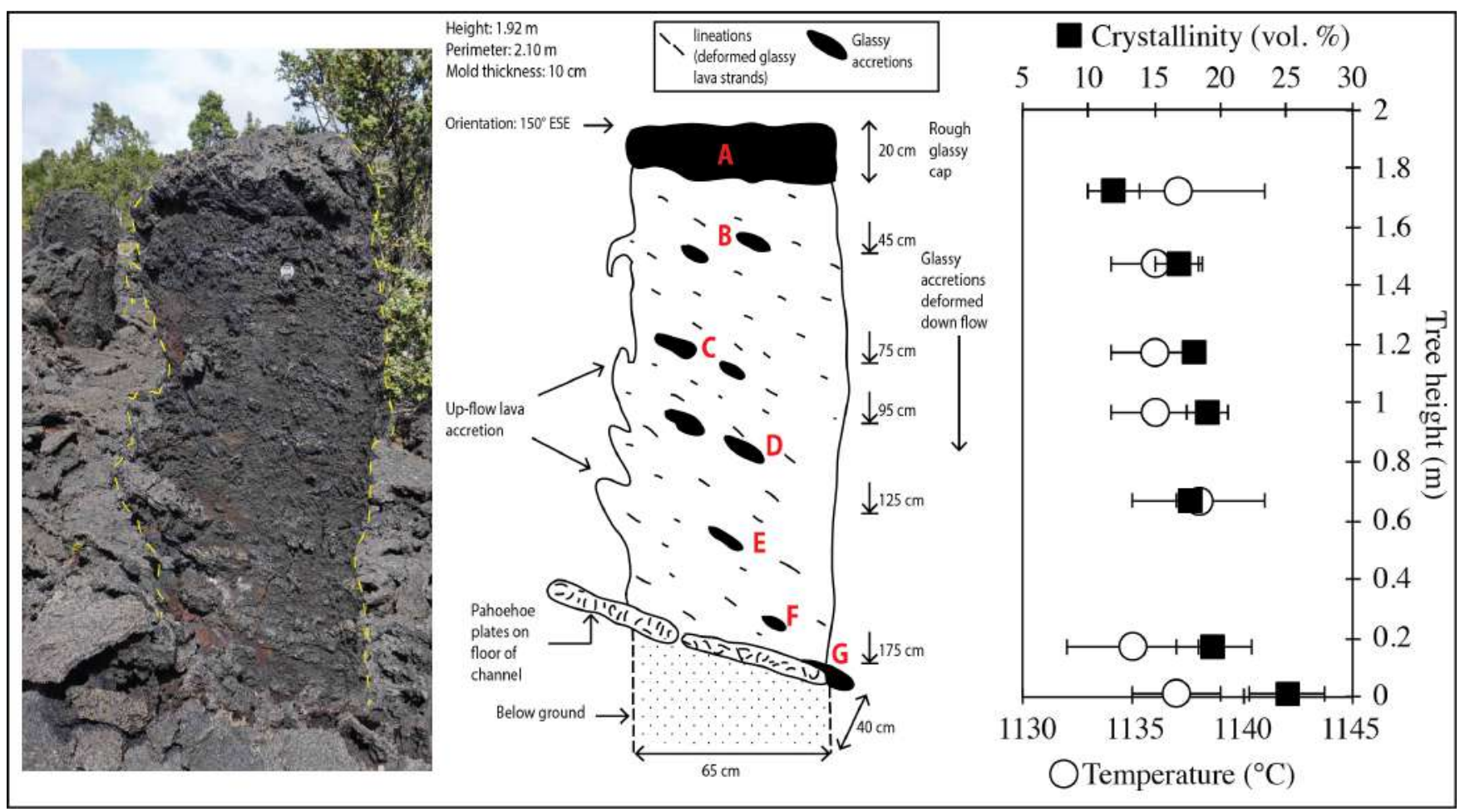


Figure 5

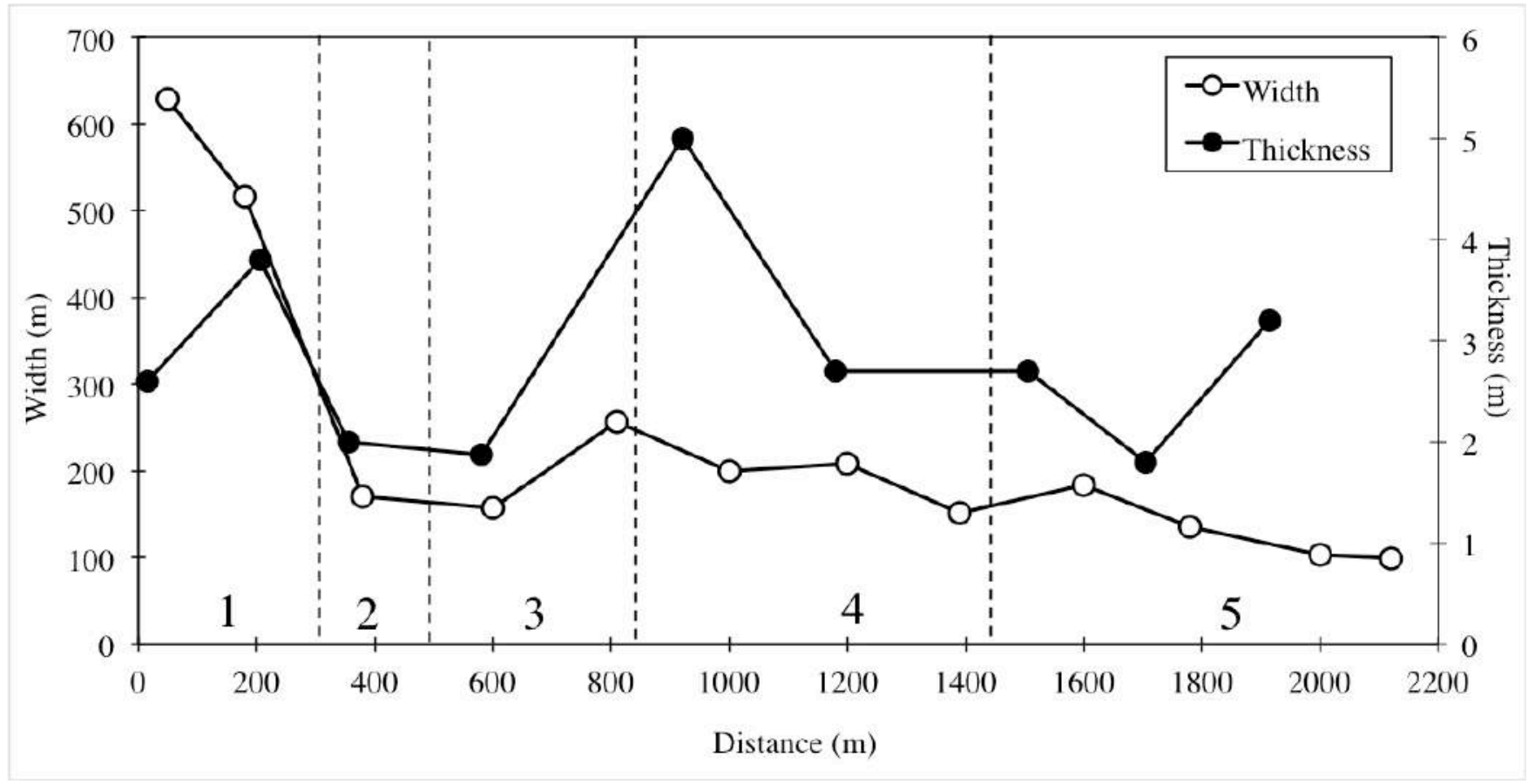


Figure 6

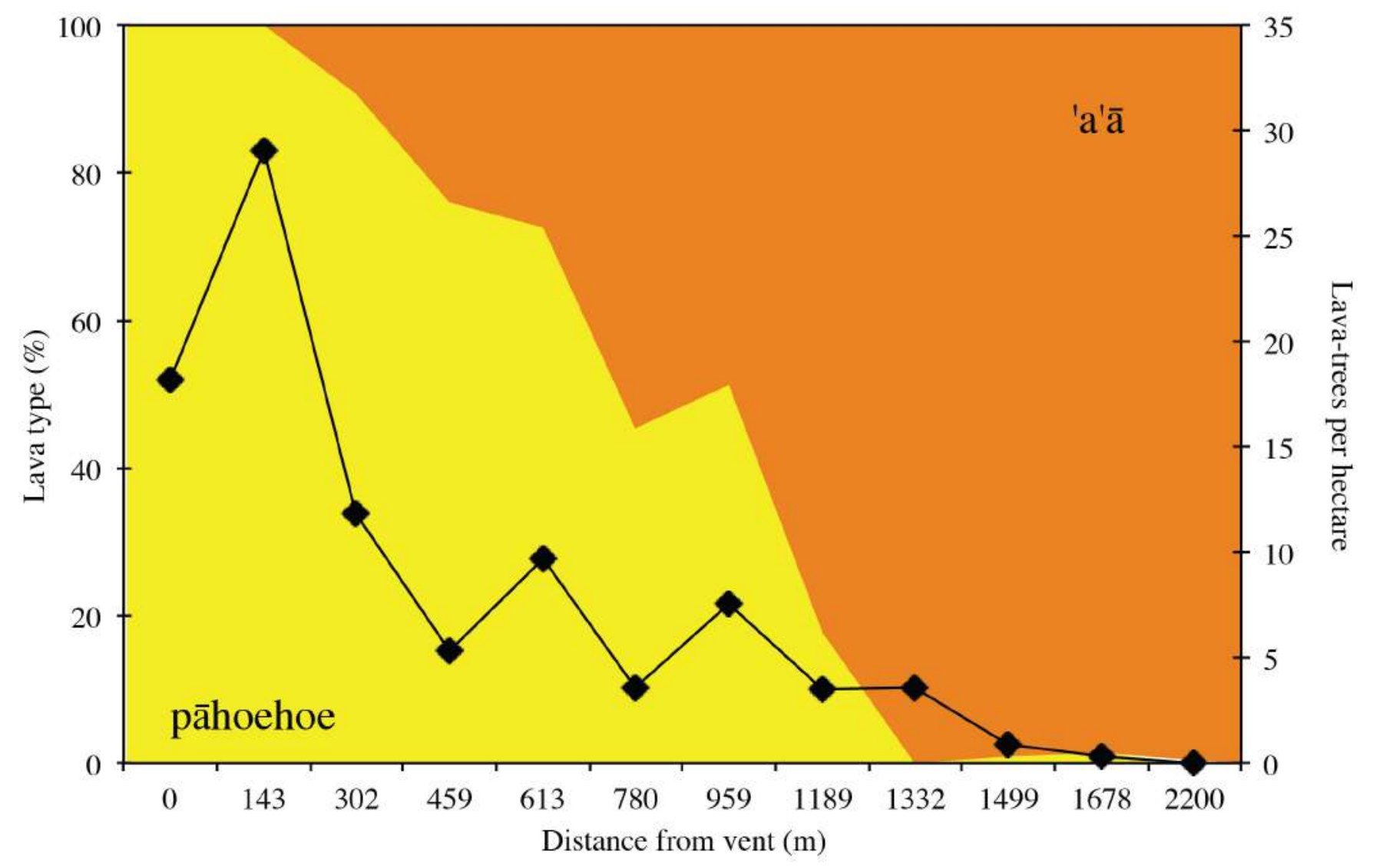


Figure 7
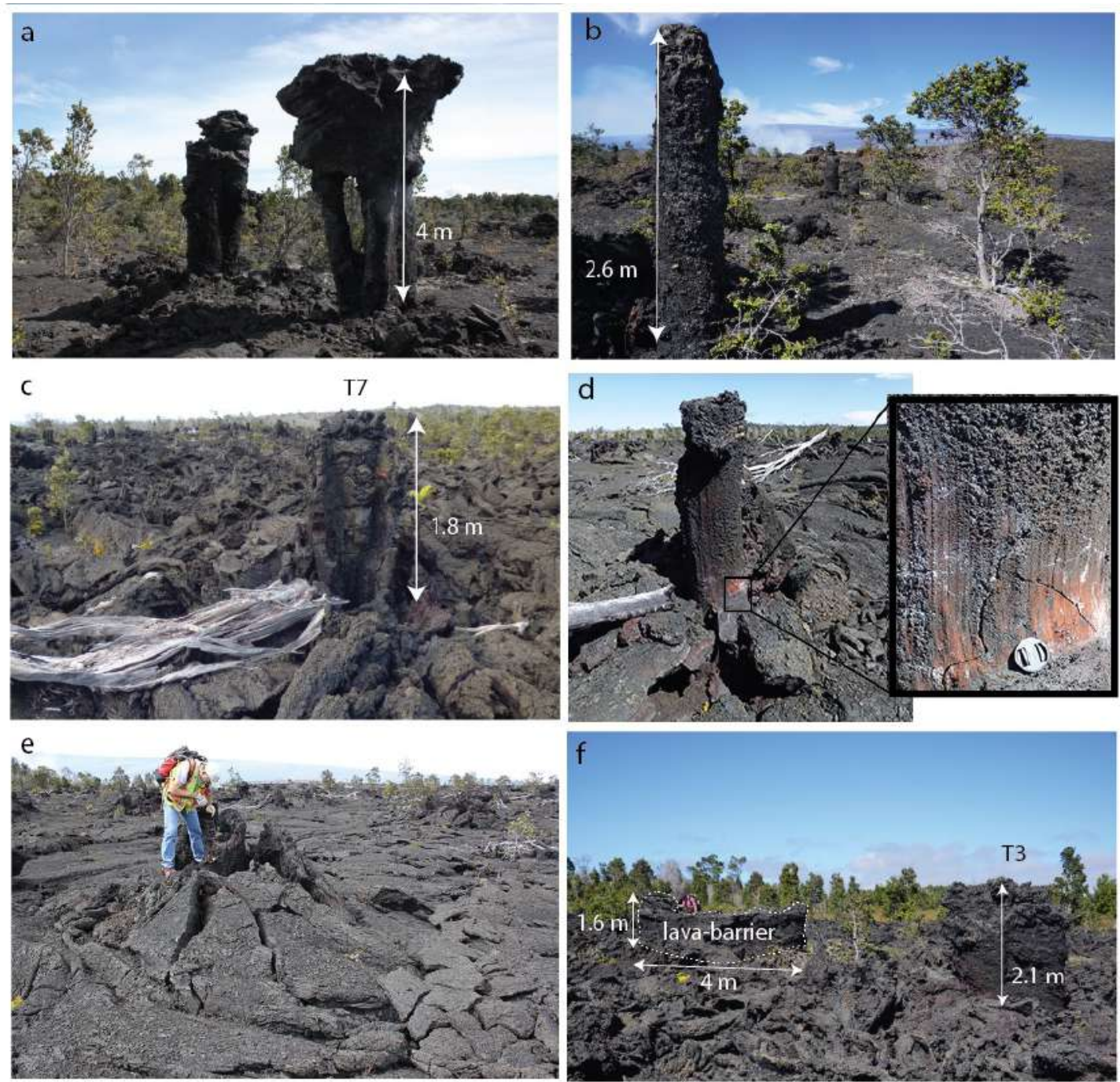
Figure 8
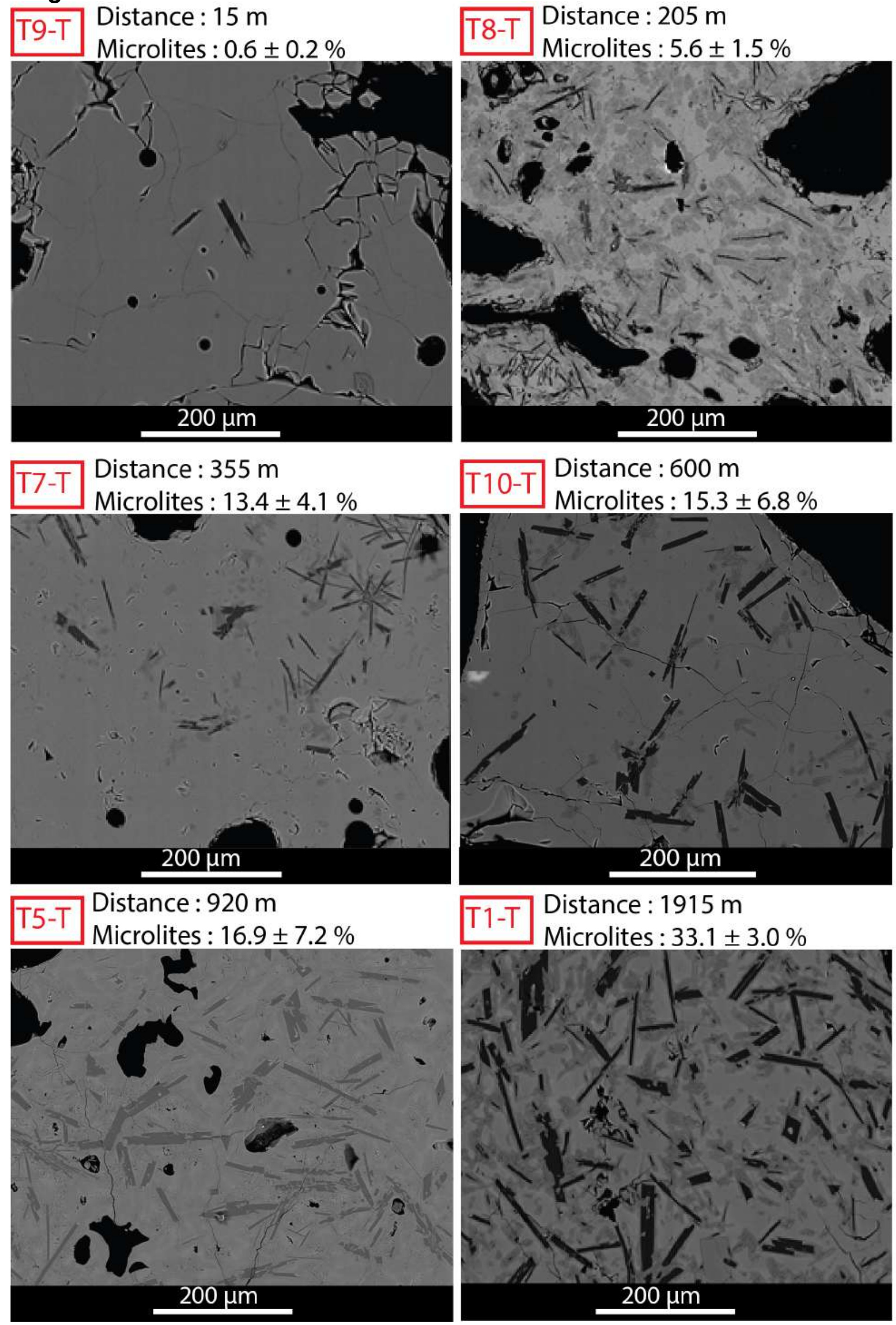
Figure 9

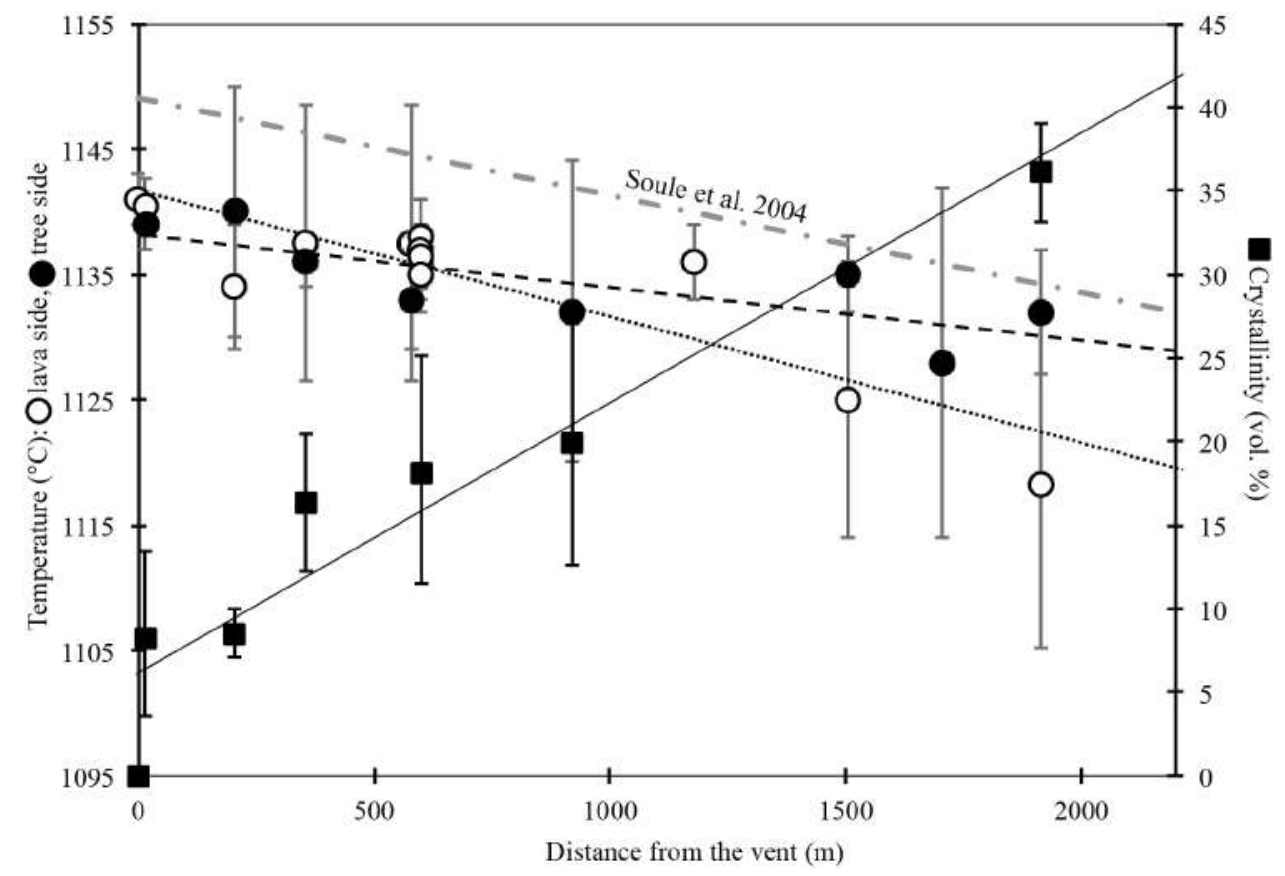


Figure 10

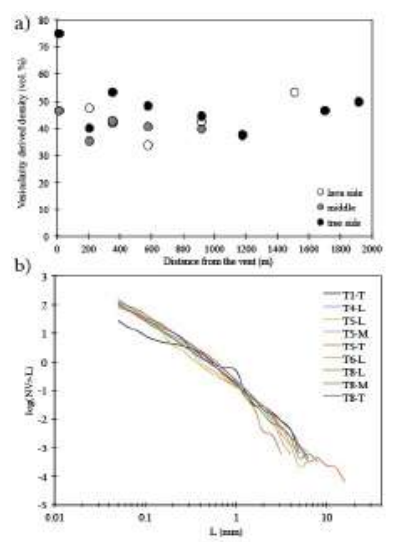


Figure 11

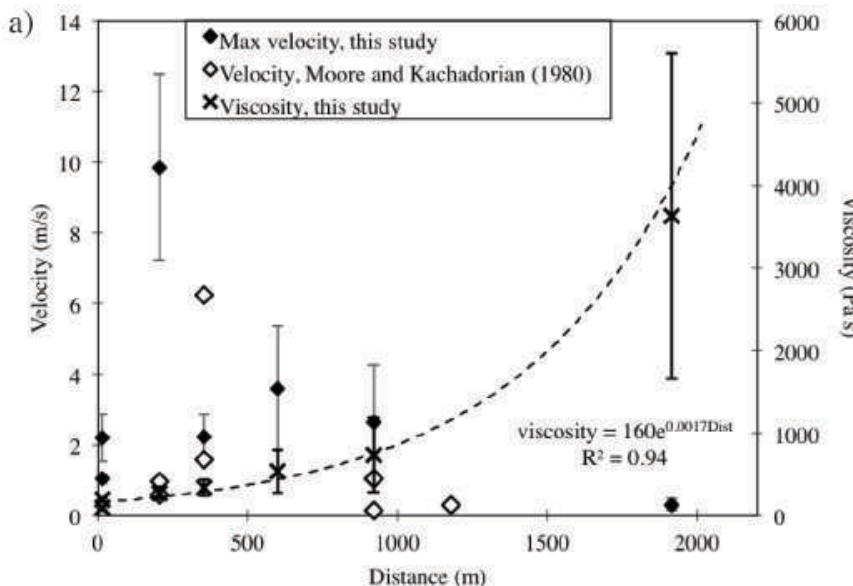

b) $\quad \times$ Viscosity (Pa s)

c. $200 \times 400 \quad 600$ ( 800 (000 1200

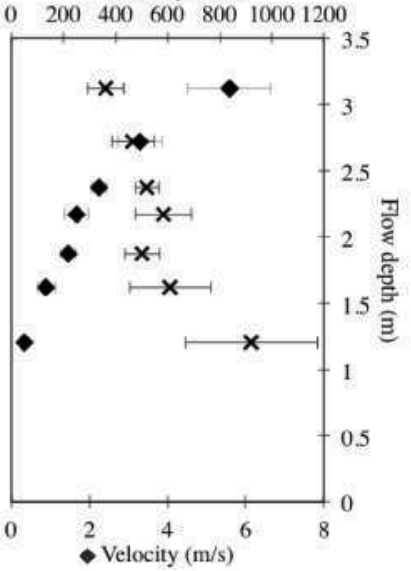




\section{Figure 12}

Pāhoehoe lava flow: preserving environment Formation of lava-tree and local flow diversion

Aerial view

Scattered forest

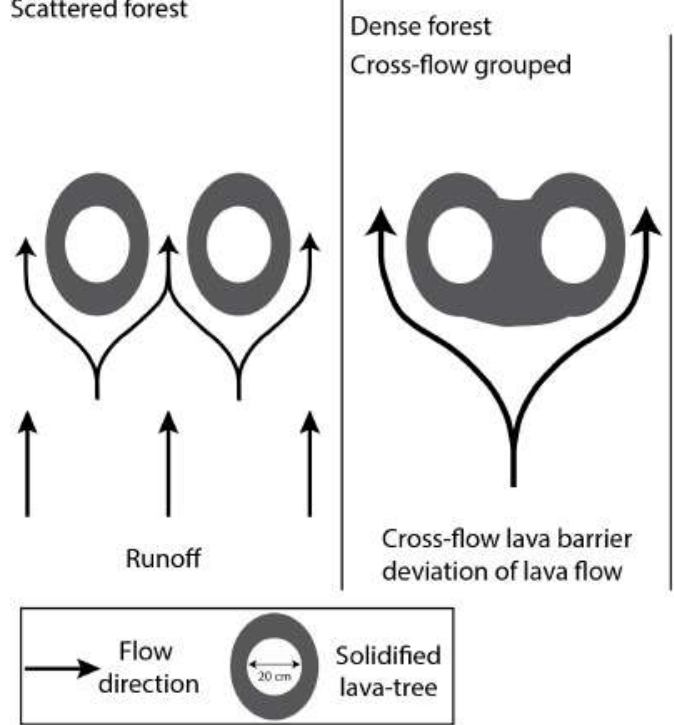

Down-flow grouped
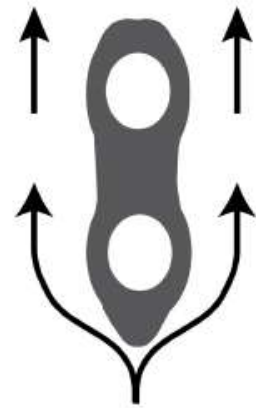

Down-flow lava barrier deviation of lava flow

viscosity $<1000 \mathrm{~Pa}$ s velocity $>1 \mathrm{~m} / \mathrm{s}$
'A'ã lava flow: destructive environment Bulldozer effect: no lava-tree

Lateral view

Lava advancing toward a forest
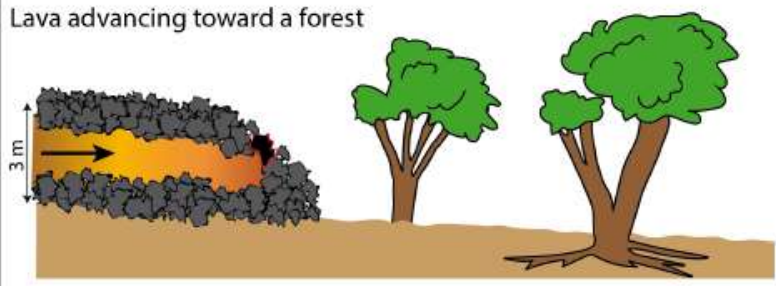

Lava overriding trees

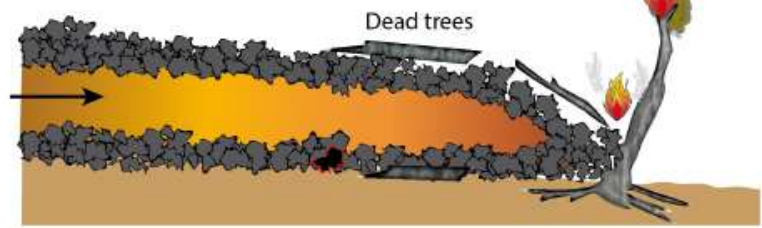

viscosity $>1000 \mathrm{~Pa} s$ velocity $<1 \mathrm{~m} / \mathrm{s}$

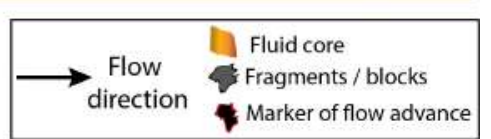




\section{Table 1}

\begin{tabular}{|c|c|c|c|c|c|}
\hline \multirow{2}{*}{ Sample } & \multicolumn{2}{|c|}{ GPS coordinates } & \multirow{2}{*}{$\begin{array}{l}\text { Distance from } \\
\text { vent }(\mathrm{m})\end{array}$} & \multirow{2}{*}{$\begin{array}{l}\text { Height of the } \\
\text { lava-tree }(\mathrm{m})\end{array}$} & \multirow{2}{*}{ Description } \\
\hline & Latitude $(\mathrm{N})$ & Longitude (W) & & & \\
\hline Vent & $19^{\circ} 23^{\prime} 57.8710^{\prime \prime}$ & $155^{\circ} 15^{\prime} 29.6680^{\prime \prime}$ & 0 & -- & Glassy spatter $t$ vent \\
\hline T9 & $19^{\circ} 23^{\prime} 57.3504^{\prime \prime}$ & $155^{\circ} 15^{\prime} 29.5245^{\prime \prime}$ & 15 & 2.6 & $\begin{array}{l}\text { Near the vent, sheet } \\
\text { pahoehoe }\end{array}$ \\
\hline $\mathrm{T} 8$ & $19^{\circ} 23^{\prime} 51.2160^{\prime \prime}$ & $155^{\circ} 15^{\prime} 28.5489^{\prime \prime}$ & 205 & 3.8 & Sheet pahoehoe zone \\
\hline $\mathrm{T} 7$ & $19^{\circ} 23^{\prime} 46.4604^{\prime \prime}$ & $155^{\circ} 15^{\prime} 29.3742^{\prime \prime}$ & 355 & 2 & $\begin{array}{l}\text { Gas-rich zone, shelly } \\
\text { pahoehoe }\end{array}$ \\
\hline $\mathrm{T} 6$ & $19^{\circ} 23^{\prime} 39.4332^{\prime \prime}$ & $155^{\circ} 15^{\prime} 27.0157^{\prime \prime}$ & 580 & 1.88 & $\begin{array}{l}\text { Shear zone in the } \\
\text { channel, slabby pahoehoe }\end{array}$ \\
\hline T10 & $19^{\circ} 23^{\prime} 39.0408^{\prime \prime}$ & $155^{\circ} 15^{\prime} 24.6118^{\prime \prime}$ & 600 & 1.92 & $\begin{array}{l}\text { Near T6, edge of the } \\
\text { channel }\end{array}$ \\
\hline T5 & $19^{\circ} 23^{\prime} 29.2380^{\prime \prime}$ & $155^{\circ} 15^{\prime} 23.2431^{\prime \prime}$ & 920 & 5 & $\begin{array}{l}\text { Tree with three trunks, in } \\
\text { channel of slabby } \\
\text { pahoehoe }\end{array}$ \\
\hline $\mathrm{T} 4$ & $19^{\circ} 23^{\prime} 23.8272^{\prime \prime}$ & $155^{\circ} 15^{\prime} 16.5212^{\prime \prime}$ & 1180 & 2.7 & Slabby pahoehoe \\
\hline $\mathrm{T} 3$ & $19^{\circ} 23^{\prime} 14.9604^{\prime \prime}$ & $155^{\circ} 15^{\prime} 10.4030^{\prime \prime}$ & 1505 & 2.7 & $\begin{array}{l}\text { Slabby pahoehoe to 'a'a } \\
\text { lava }\end{array}$ \\
\hline $\mathrm{T} 2$ & $19^{\circ} 23^{\prime} 08.8764^{\prime \prime}$ & $155^{\circ} 15^{\prime} 08.1606^{\prime \prime}$ & 1705 & -- & $\begin{array}{l}\text { Slabby pahoehoe to 'a'a } \\
\text { lava }\end{array}$ \\
\hline $\mathrm{T} 1$ & $19^{\circ} 23^{\prime} 04.0596^{\prime \prime}$ & $155^{\circ} 15^{\prime} 03.2633^{\prime \prime}$ & 1915 & 3.2 & $\begin{array}{l}\text { First lava tree found } \\
\text { since the front, } \\
\text { essentially 'a'a lava }\end{array}$ \\
\hline
\end{tabular}




\section{Table 2}

\begin{tabular}{|c|c|c|c|c|c|c|c|c|c|c|}
\hline Sample & $\begin{array}{l}\text { Distance from } \\
\text { vent }(m)\end{array}$ & $\begin{array}{c}\text { Number of glass } \\
\text { per sample }\end{array}$ & $\begin{array}{c}\text { Temperature } \\
\qquad 1^{*} \mathrm{C}\end{array}$ & $+/$ & $\begin{array}{l}\text { Density } \\
(\mathrm{kg} / \mathrm{m} 3)\end{array}$ & $\begin{array}{l}\text { vesicularity-derived } \\
\text { density (vol. \%) }\end{array}$ & $\begin{array}{l}\text { 2D vesicularity } \\
\text { (vol. \%) }\end{array}$ & $\begin{array}{l}\text { Microlite (vol. } \\
\% \text { ) }\end{array}$ & $\begin{array}{l}\text { Total crystal } \\
\text { content (vol. } \\
\% \text { \%)** }\end{array}$ & $+1-$ \\
\hline VENT & 0 & 20 & 1141 & 2 & - & -- & - & - & 3 & - \\
\hline T9-L & 15 & 11 & 1140 & 2 & - & - & - & 10.5 & 13.5 & 1.6 \\
\hline T9-M & 15 & - & - & - & 1620 & 46.5 & - & - & - & - \\
\hline T9-T & 15 & 10 & 1139 & 2 & 756 & 75.1 & - & 0.6 & 3.6 & 0.2 \\
\hline T8-L & 205 & 10 & 1134 & 5 & 1599 & 47.2 & 44.4 & - & - & - \\
\hline T8-M & 205 & - & - & - & 1959 & 35.4 & 38.4 & - & - & - \\
\hline T8-T & 205 & 30 & 1140 & 10 & 1811 & 40.2 & 54.8 & 5.6 & 8.6 & 1.4 \\
\hline T7-L & 355 & 10 & 1138 & 11 & 1757 & 42.0 & - & - & - & - \\
\hline T7-M & 355 & - & - & - & 1743 & 42.5 & - & - & - & - \\
\hline T7-T & 355 & 10 & 1136 & 2 & 1416 & 53.3 & - & 13.4 & 16.4 & 4.1 \\
\hline T6-L & 580 & 10 & 1138 & 11 & 2001 & 34.0 & 37.6 & - & - & - \\
\hline T6-M & 580 & - & - & - & 1798 & 40.7 & - & - & - & - \\
\hline T6-T & 580 & 10 & 1133 & 4 & 1566 & 48.3 & - & - & - & - \\
\hline T10-L mean & 600 & -- & 1136 & 3 & - & - & - & 15.3 & 18.3 & 6.8 \\
\hline T5-L & 920 & - & - & - & 1749 & 42.3 & 40.8 & - & - & - \\
\hline T5-M & 920 & - & - & - & 1821 & 39.9 & 39.1 & - & - & - \\
\hline TS-T & 920 & 11 & 1132 & 12 & 1677 & 44.6 & 60.4 & 16.8 & 19.8 & 7.2 \\
\hline T4-L & 1180 & 10 & 1136 & 3 & 1887 & 37.7 & 44.6 & - & - & - \\
\hline T4-T & 1180 & -- & - & - & 1898 & 37.4 & - & - & - & - \\
\hline T3-L & 1505 & 10 & 1125 & 11 & 1412 & 53.4 & - & - & - & - \\
\hline Т3-Т & 1505 & 10 & 1135 & 3 & 1507 & 50.3 & -. & -. & -. & - \\
\hline T2-L & 1705 & - & - & - & 0 & - & - & - & - & - \\
\hline T2-T & 1705 & 10 & 1128 & 14 & 1626 & 46.3 & - & - & - & - \\
\hline T1-L & 1915 & 10 & 1118 & 13 & 0 & -- & - & - & - & - \\
\hline T1-T & 1915 & 15 & 1132 & 5 & 1522 & 49.8 & 54.3 & 33.1 & 36.1 & 3.0 \\
\hline
\end{tabular}




\section{Table 3}

\begin{tabular}{|c|c|c|c|c|c|c|c|c|c|c|c|c|c|c|c|c|c|}
\hline \multirow[t]{2}{*}{ Level } & \multirow[t]{2}{*}{ Sample } & \multirow[t]{2}{*}{$\begin{array}{l}\text { Distance from } \\
\text { top (m) }\end{array}$} & \multirow[t]{2}{*}{ Flow Depth (m) } & \multicolumn{2}{|c|}{$\begin{array}{l}\text { Temperature } \\
\left({ }^{\circ} \mathrm{C}\right) \mathrm{a}\end{array}$} & \multicolumn{2}{|c|}{$\begin{array}{l}\text { Melt viscosity } \\
\text { (Pa s)b }\end{array}$} & \multicolumn{2}{|c|}{$\begin{array}{l}\text { Crystallinity } \\
\text { (vol.\%)c }\end{array}$} & \multicolumn{2}{|c|}{$\begin{array}{l}\text { Relative viscosity } \\
\text { crystal effectd }\end{array}$} & \multicolumn{2}{|c|}{$\begin{array}{l}\text { Viscosity of three } \\
\text { phase mixture (Pa } \\
\text { s)e }\end{array}$} & \multicolumn{2}{|c|}{ Velocity $(m / s) f$} & \multicolumn{2}{|c|}{$\begin{array}{c}\text { Effusion Rate } \\
(\mathrm{m} 3 / \mathrm{s})\end{array}$} \\
\hline & & & & & \pm & & \pm & & \pm & & \pm & & \pm & & \pm & & \pm \\
\hline High-Stand & A & 0 & 3.12 & 1137 & 4 & 481 & 27 & 11.9 & 2.0 & 1.8 & 0.6 & 363 & 124 & 5.6 & 1.9 & 304 & 58 \\
\hline 1 & B & 0.4 & 2.72 & 1137 & 2 & 460 & 22 & 16.9 & 1.7 & 2.4 & 0.5 & 467 & 99 & 3.3 & 0.7 & 157 & 27 \\
\hline 2 & c & 0.75 & 2.37 & 1136 & 2 & 475 & 14 & 18.0 & 0.3 & 2.6 & 0.1 & 520 & 24 & 2.2 & 0.1 & 93 & 8 \\
\hline 3 & D & 0.95 & 2.17 & 1136 & 2 & 498 & 28 & 19.0 & 1.6 & 2.7 & 0.5 & 583 & 101 & 1.7 & 0.3 & 64 & 12 \\
\hline 4 & E & 1.25 & 1.87 & 1138 & 3 & 469 & 19 & 17.7 & 1.0 & 2.5 & 0.3 & 502 & 61 & 1.4 & 0.2 & 47 & 6 \\
\hline 5 & F & 1.5 & 1.62 & 1135 & 3 & 505 & 29 & 19.5 & 2.9 & 2.8 & 0.8 & 610 & 185 & 0.9 & 0.3 & 25 & 6 \\
\hline Low-Stand & $\mathrm{G}$ & 1.75 & 1.20 & 1137 & 2 & \multirow{2}{*}{\multicolumn{2}{|c|}{$\begin{array}{rl}491 & 20 \\
\end{array}$}} & 25.1 & 2.9 & 4.4 & 1.0 & 921 & 213 & 0.3 & 0.1 & 7 & 2 \\
\hline \multicolumn{6}{|c|}{ a Mg-thermometer from 10 glass analyses per sample } & & & & & & & & & $0.48(\mathrm{r}=$ & & & \\
\hline $\mathrm{b}$ caluclated vi & Giordano & et al. 2008 & & & & \multirow{2}{*}{\multicolumn{8}{|c|}{$\begin{array}{l}\text { e considering } 40+/ 0.1 \% \text { of deformable bubble via Llewelin and Manga } 2005 \\
\text { f Jeffreys equation with slope of } 2^{\circ} \text { and density of } 1.82\end{array}$}} & & & & \\
\hline$c$ including ph & sts a & olites & & & & & & & & & & & & & & & \\
\hline
\end{tabular}


Table 4

\begin{tabular}{|c|c|c|c|c|c|c|c|c|c|c|c|c|c|}
\hline \multirow[t]{2}{*}{ Tree } & \multirow[t]{2}{*}{ Zone } & \multirow[t]{2}{*}{$\begin{array}{l}\text { Distance from } \\
\text { vent }(\mathrm{m})\end{array}$} & \multirow[t]{2}{*}{$\begin{array}{l}\text { Max flow } \\
\text { Depth (m) }\end{array}$} & \multirow[t]{2}{*}{$\begin{array}{l}\text { Final Flow } \\
\text { Depth }(\mathrm{m})\end{array}$} & \multirow[t]{2}{*}{ Slope $\left(^{\circ}\right)$} & \multicolumn{2}{|c|}{$\begin{array}{l}\text { Melt viscosity (Pa } \\
\text { s)a }\end{array}$} & \multicolumn{2}{|c|}{$\begin{array}{l}\text { Viscosity of three } \\
\text { phase mixture (Pa s)b }\end{array}$} & \multicolumn{2}{|c|}{$\begin{array}{c}\text { Max velocity } \\
(\mathrm{m} / \mathrm{s}) \mathrm{c}\end{array}$} & \multicolumn{2}{|c|}{$\begin{array}{c}\text { Min velocity } \\
(\mathrm{m} / \mathrm{s}) \mathrm{c}\end{array}$} \\
\hline & & & & & & & \pm & & \pm & & \pm & & \pm \\
\hline T9-T & 1: sheet flow & 15 & 2.6 & 0.9 & 0.3 & 471 & 54 & 193 & 23 & 1.0 & 0.1 & 0.1 & $\overline{0.0}$ \\
\hline T9-L & 1: sheet flow & 15 & 2.6 & 0.9 & 0.3 & 478 & 41 & 91 & 28 & 2.2 & 0.7 & 0.3 & 0.1 \\
\hline T8 & 1: sheet flow & 205 & 3.8 & 2.4 & 1.9 & 441 & 113 & 277 & 74 & 9.8 & 2.6 & 3.9 & 1.1 \\
\hline $\mathrm{T} 7$ & 2: proximal channel & 355 & 2.0 & 0.2 & 1.9 & 523 & 61 & 338 & 97 & 2.2 & 0.6 & 0.01 & 0.0 \\
\hline T6 & 3: Medial channel & 580 & 1.9 & 0.7 & 2.0 & -- & -- & -- & -- & -- & - & $\ldots$ & -. \\
\hline $\mathrm{T} 10$ & 3: Medial channel & 600 & 3.1 & 1.7 & 2.0 & 483 & 164 & 538 & 263 & 3.6 & 1.8 & 1.1 & 0.5 \\
\hline T5 & 3: Medial channel & 920 & 5.1 & 1.7 & 0.8 & 678 & 236 & 735 & 457 & 2.6 & 1.6 & 0.3 & 0.2 \\
\hline T4 & 4. Distal channel & 1180 & 2.7 & 1.4 & 0.8 & $\ldots$ &.- & $\ldots$ & -- & -. &.- & -- & -. \\
\hline Т3 & 5. Dispersed flow & 1505 & 2.7 & 0.6 & 0.8 & -- & -- & -- & -- & -- & -- & -- & - \\
\hline $\mathrm{T} 2$ & 5. Dispersed flow & 1705 & 1.8 & 1.8 & 1.1 & .- & .. & .- & -. & -. & - & - & \\
\hline $\mathrm{T} 1$ & 5. Dispersed flow & 1915 & 3.2 & 1.2 & 1.1 & 702 & 145 & 3634 & 1975 & 0.3 & 0.2 & 0.04 & 0.02 \\
\hline & & 1915 & & & & & & & & & & & \\
\hline & & & & & & & & & & & & & \\
\hline & effreys equation wi & & & & & & & & & & & & \\
\hline
\end{tabular}




\section{Table 5}

\begin{tabular}{ccccc} 
Time (hours) & Effusion Rate & $(\mathrm{m} 3 / \mathrm{s})$ & Duration (h) & $\begin{array}{c}\text { Volume } \\
\text { Emplaced (m3) }\end{array}$ \\
\hline 1.8 & 403 & 1.8 & $2.55 \times 106$ \\
2.6 & 209 & 0.9 & $6.57 \times 105$ \\
3.1 & 124 & 0.4 & $1.95 \times 105$ \\
3.3 & 85 & 0.2 & $6.68 \times 104$ \\
3.4 & 63 & 0.1 & $2.48 \times 104$ \\
3.4 & 34 & 0.05 & $6.64 \times 103$ \\
\hline 3.5 & 9 & 0.03 & $8.93 \times 102$ \\
\hline Total & 280 & 3.5 & $3.5 \times 106$ \\
\hline
\end{tabular}

